\title{
Does the Choice Between Listing on the NYSE Versus Nasdaq Matter? An Examination of Firms that Voluntarily Move from the NYSE to Nasdaq
}

\author{
Dung (Yom) Bui \\ University of Wisconsin, Eau Claire \\ Don Chance \\ Louisiana State University \\ Clifford Stephens \\ Louisiana State University
}

This paper provides an update to the body of research on the competition between the New York Stock Exchange and Nasdaq. We examine 49 firms that voluntarily moved from the NYSE to Nasdaq from 20002013 to determine if there are economic benefits to switching exchanges. We find no evidence of any significant economic benefit, and little evidence of an industry clientele effect; switching firms tend to be more like an NYSE firm than a Nasdaq firm and there is little market reaction to the switch announcement. We conclude that the two exchanges appear to be in a state of parity.

Keywords: New York Stock Exchange, Nasdaq, Exchange Listing

\section{INTRODUCTION}

Publicly held companies have a choice of exchanges on which their stock will trade. While securities exchanges impose certain requirements that companies must meet and maintain, for the most part, reasonably large and successful companies can choose where their stock is listed. In the United States, that choice is generally between the New York Stock Exchange (NYSE) and Nasdaq. ${ }^{1}$

For roughly the first 30 years since the founding of Nasdaq in 1971, tradition was that many newlylisted firms began publicly trading on Nasdaq and as the firms grew, became more profitable, and began paying dividends, they would often change their stock listing to the NYSE. ${ }^{2}$ In this sense, listing first on Nasdaq and then moving to the NYSE was much like the process in which a baseball player starts off in the minor leagues and if sufficiently successful, moves on to the major leagues. For nearly a quarter century, Nasdaq played this role of a minor league for young developing companies; but times have since changed. Many mature and mega-cap firms such as Apple and Microsoft that originally listed on Nasdaq have chosen to remain there, and of course Google and Facebook originally listed on Nasdaq and seem likely to stay there. Thus, it could be the case that U. S. equity markets may have reached a stage in the evolutionary process in which the two exchanges have achieved a balanced attractiveness that makes neither clearly superior to the other. This state of competitiveness raises questions about whether the 
exchange a stock is listed on matters at all. Would it make a difference if the stock were listed on Nasdaq or the NYSE? Could a company just toss a coin to determine where to list?

It is tempting to argue that this fact is prima facie true. Yet, if firms continue to be listed on Nasdaq and some move to the NYSE but no firms move from the NYSE to Nasdaq, then the exchanges have not reached parity. Prior to 2000, no firms voluntarily moved from the NSYE to Nasdaq - the perceived minor league. From 2000 through 2013, however, forty-nine companies jumped from the NYSE to Nasdaq. If the movement between exchanges is now a free-flowing path in both directions with no perceived economic benefits, the two exchanges should perhaps be viewed as more like what happened in professional football in the 1960s and early 1970s.

The National Football League was founded in 1920. In 1960, a new rival, the American Football League, was created and began to offer some competition for talent. Although players and teams did not generally move from the AFL to the NFL, it was clear that the NFL was the superior league. In 1964, however, University of Alabama quarterback Joe Namath, the $12^{\text {th }}$ player selected in the NFL draft, surprised everyone and signed with the New York Jets of the AFL. No longer was the AFL getting second-rate players. Starting to feel competitive pressure, three years later the NFL agreed to a merger with the AFL and instituted a championship game that would come to be known as the Super Bowl. In 1969 Namath led his New York Jets to a victory over the NFL's heavily favored champion, the Baltimore Colts. The two leagues, which by 1970 had become known as conferences rather than leagues, were now clearly equal. In fact, that year three teams, the Pittsburgh Steelers, the Cleveland Browns and the Baltimore Colts, moved from the National Football Conference to the American Football conference, which they certainly would not have agreed to do were the conferences not at parity. Clearly it no longer mattered which conference a player or a team was in.

The existence of movements from the NYSE to Nasdaq does not, however, in and of itself demonstrate parity. If there are clear economic reasons for such movements, such as to save costs, then Nasdaq may well have become the major leagues. It is also possible, if not likely, that for some types of firms, the NYSE would be the better exchange, while for other types of firms, the Nasdaq would be optimal. If there are, however, no measurable economic benefits, then a stock is likely to choose its exchange based on clientele effects, such as where its industry trades, or for some other largely immeasurable reason. These "soft" reasons suggest that the exchanges may be in a state of parity.

In this paper we use the movement of 49 firms from the NYSE to Nasdaq during the period 20002013 to determine if there are economic benefits to switching exchanges and if exchange listing matters. If these movements were justifiable in economic terms, then Nasdaq is clearly drawing firms from the NYSE on an economic basis and is likely to increasingly do so. If these movements cannot be explained in economic terms, then the exchanges are likely in a state of parity, and firms will choose where to list based on non-economic factors.

This paper comprehensively updates the body of research and general state of acceptance that the NYSE is the preferred and more prestigious exchange. We find that there appear to be no documentable economic benefits to moving from the NYSE to Nasdaq and even some costs, such as lower liquidity. Yet, corporations may care little about the higher bid-ask spreads on their stock, as it tends to discourage short-term speculation that firms may view as undesirable. We also find little evidence of a significant market reaction upon the announcement of a switch. In undertaking this analysis, we develop a relatively parsimonious model that predicts with a high degree of accuracy the exchange on which a firm is listed. Interestingly, our analysis shows that these firms that left the NYSE for Nasdaq are far more like the NYSE firms they leave than the Nasdaq firms they join. In fact, we find no support for the notion that many tech firms prefer Nasdaq because it is viewed as a tech exchange; it is no more of a tech exchange than is the NYSE. We also find that there is no tendency for the industries of the switching firms to prefer Nasdaq. We do find, however, that the leading firms in the industries of the firms that move tend to be on Nasdaq. Thus, there may be a follow-the-leader story behind these moves. Whatever reasons that motivate these switches appear to be "soft" reasons that cannot be quantified. As such, firms may have little preference, nor may it matter much economically on which exchange their shares are traded. 
The remainder of this paper is organized as follows: we briefly review the pertinent literature on exchange choice and exchange switches in section 2, we describe our sample and empirical method in section 3, we report our empirical results in section 4 and we provide our conclusions in section 5.

\section{THE ISSUES, MARKET STRUCTURE, AND PREVIOUS RESEARCH}

We begin with an overview of the structure of the markets and an examination of previous research on the factors that could lead to a change in the exchange on which a stock is listed, and, thus, a preference for one exchange over the other.

\section{Market Organization and Institutional Features}

The primary distinction between the New York Stock Exchange and Nasdaq is traditionally the market maker system. Nasdaq is a dealer market in which multiple dealers promote their listings, compete for public trades, and in which each stock has multiple dealers. The NYSE is traditionally a specialist market in which one firm serves as the sole market maker. Nasdaq traditionally touts the competitive nature of its structure, while the NYSE argues that a specialist can provide greater service. Both the NYSE and Nasdaq aggressively market their services to attract listings and volume, and as noted recently in the Wall Street Journal (Loder, 2016), "NYSE's competitors have made inroads by offering cheaper or fee-free listings along with sweeteners like advertising on Nasdaq's huge electronic billboards in Times Square." Although marketing by the exchanges could play a critical role in the firm's exchange choice, our research focuses on economic factors such as improvements in investor recognition or visibility, liquidity or trading costs, profitability and valuation from changing exchanges. ${ }^{3}$

Another distinguishing feature, at least in past years, is that NYSE trading was traditionally face-toface, while Nasdaq trading has always been indirect, either through telephone lines or by computer. In removing a tangible element of the human process from trading, a trader could no longer attempt to read signals from other traders, a trait that traders anecdotally seem to believe is important. Physical advantages, such as being taller or louder, that grant the ability to draw attention, are neutralized when the trading floor is eliminated. To some, this change would be seen as an improvement, while to others it would be seen as detrimental. In recent years, perhaps from competitive pressures, the NYSE has gone to the more electronic impersonal model. In 2005, it acquired Archipelago, an electronic trading platform, and in 2007, it began to permit all of its listed stocks to be traded electronically. The NYSE is now a hybrid market and it is estimated that floor trading now accounts for no more than $15 \%$ of NYSE volume (Hiltzik (2014)). In addition, in 2005, Nasdaq acquired Instinet, a global electronic trading market, extending its commitment to electronic trading.

Aggarwal and Angel (1998) suggest that some firms may prefer the particular market structure of one exchange versus others. This may lead to a clientele effect, where particular types of firms or industries prefer one market or market structure to the other. Additionally, there is at least anecdotal evidence that some industries prefer one exchange to the other. For instance, Nasdaq is traditionally thought of as the tech exchange, while oil and gas firms seem to prefer NYSE. ${ }^{4}$

\section{Previous Studies on the Motivation and Timing of an Exchange Switch}

Merton (1987) derives a model of capital market equilibrium with incomplete information that shows that an increase in investor recognition can have the beneficial effect of lowering the expected return and cost of capital. Increased investor recognition from moving from Nasdaq to the NYSE is supported empirically by Kadlec and McConnell (1994) and Baker, Powell and Weaver (1999), though the latter attribute the effect to changes in firm size and earnings growth. Improvements in liquidity are also found by Sanger and McConnell (1986) and as are lower bid-ask spreads (Kadlec and McConnell (1994)).

Previous studies suggest a distinct pattern of returns for firms moving from Nasdaq to the NYSE. Significant positive abnormal returns are observed in the year prior to announcement through the actual move to the NYSE. After the move, firms experience significant negative abnormal returns (Sanger and McConnell (1986, 1987), Furst (1970), Van Horne (1970), and Kadlec and McConnell (1994)). ${ }^{5}$ The 
NYSE's continuing listing requirements are less stringent than their initial listing requirements, and consequently, the poor performance of firms following a move to the NYSE could be evidence of opportunistic timing (Cowan, Carter, Dark and Singh (1992) and Dharan and Ikenberry (1995)), whereby firms switch when they feel they look the best and when they anticipate possibly looking worse in the future. ${ }^{6}$ Nonetheless, opportunistic timing only attempts to explain the timing of the switch; it does not explain why a move occurs.

Despite the perceived benefits to an NYSE listing, in the late 1980s and 1990s, many Nasdaq firms that were qualified to move to the NYSE chose not to do so. Kedia and Panchapagesan (2011) report that from 1986 to 1998, only about one in every six eligible firms moved from Nasdaq to the NYSE, suggesting the beginning of the current era in which Nasdaq may be on equal if not greater footing with the NYSE. Cowan et al. (1992) show that firms leaving Nasdaq to list on the NYSE tend to have smaller market capitalization, fewer shareholders, fewer market makers, lower prices per share, and larger bid-ask spreads than Nasdaq firms that are eligible to move but choose not to do so. These firms also access capital markets more frequently with larger issues. Of course, the eligible firms that choose to remain with Nasdaq tend to be large, highly successful firms that have less need for capital market financing.

In addition to these studies of firms that make the switch from Nasdaq to the NYSE, Aggarwal and Angel (1998) examine why Nasdaq-listed firms like Microsoft and Intel, which were obviously likely candidates to move to the NYSE, had not done so at that time and to this day remain on Nasdaq. In fact, they identify over 900 Nasdaq firms that met the listing requirements of the NYSE. They argue that large institutional investors can bypass the dealer market on Nasdaq stocks, resulting in spreads that are comparable to those on the NYSE and, therefore, obviate the motivation to move. They also point out that large Nasdaq firms get this advantage for their institutional investors, while benefitting from the marketing that dealers do to retail investors. As such, they assert that Nasdaq-listed firms believe their investors do not care where the stock is listed. They also note that most brokerage firm corporations, which routinely underwrite IPOs into the Nasdaq market, are themselves primarily listed on the NYSE and are the large types of firms that do not need Nasdaq retail marketing efforts. In essence, they claim that there is likely a clientele effect based on size and investor composition. 
FIGURE 1

NUMBER OF SWITCHES FROM NASDAQ TO THE NYSE FROM 1973 TO 2013

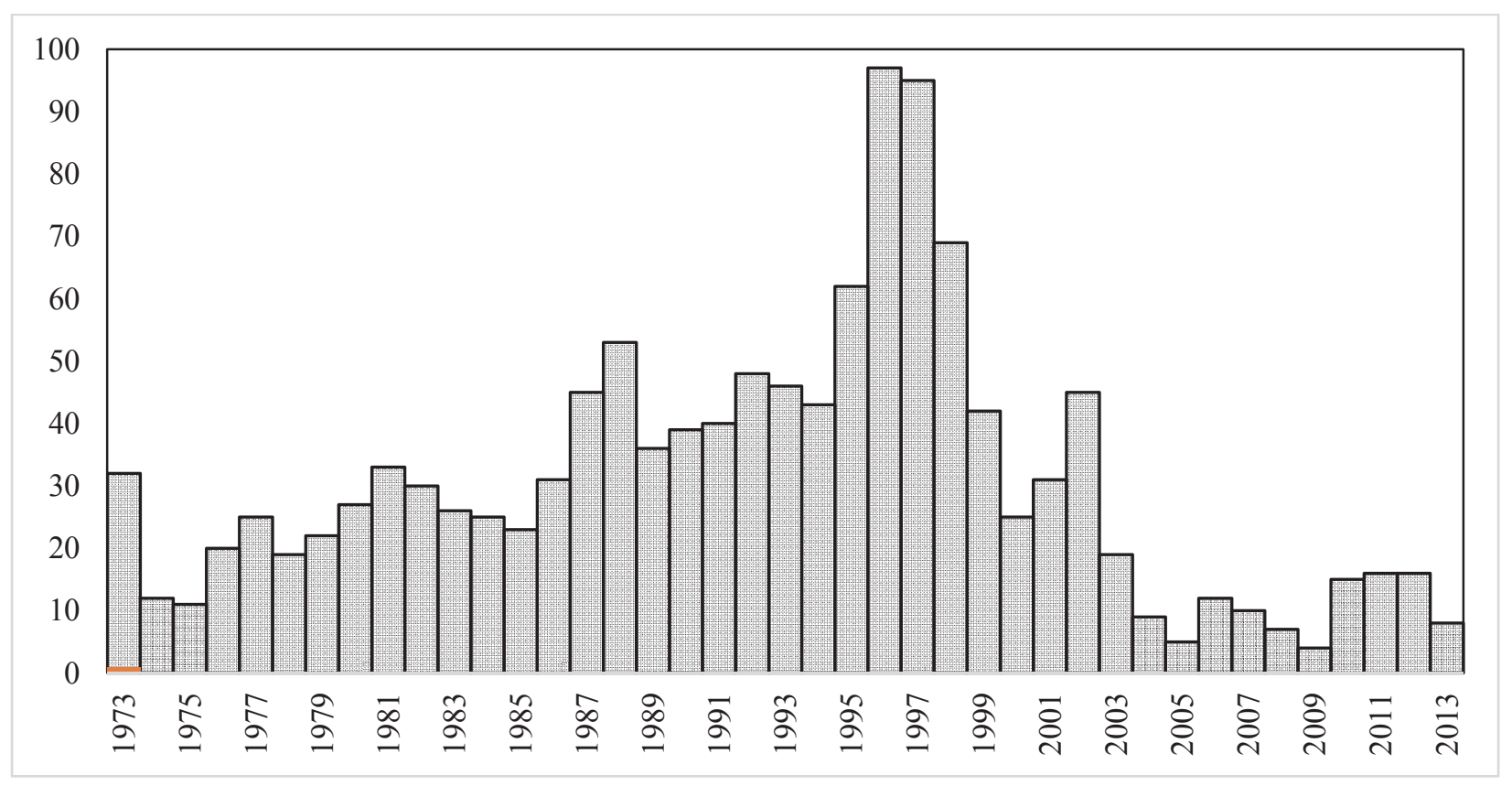

Figure 1 illustrates the number of switches from Nasdaq to the NYSE from 1973 through 2013 . We see that the number rises steadily over the period of 1973-1995, then increases sharply in 1996 and 1997 , but then begins to drop. The sharp rise from 1994 to 1998 could be partly influenced by the widely reported results of Christie and Schultz (1994) that Nasdaq market makers were implicitly colluding to keep spreads artificially wide ${ }^{7}$. To repair its tarnished image, Nasdaq subsequently instituted significant reforms, which we discuss below, and paid out more than $\$ 900$ million in late 1997 in a class-action suit. It is certainly reasonable to believe that some firms may have deserted Nasdaq for the NYSE at around that time. After 1998, the number of switches from Nasdaq to the NYSE returns to the pre-Christie and Schultz levels and drops off significantly in more recent years. The peak year for moves to the NYSE is 1996, when 97 firms switched from Nasdaq to the NYSE. In 2000, only 25 firms made the switch and in 2014, there were only eight firms that switched to the NYSE. So not only have we observed an increasing number of firms switching from the NYSE to Nasdaq, but we also seem to have observed a decreasing number of Nasdaq firms switching to the NYSE.

\section{Moving from AMEX to Nasdaq}

Clyde, Schultz, and Zaman (1997) examine 47 firms that move from the AMEX to Nasdaq from 1992 through 1995. The market reacts positively to the announcement of the switch, though the response is only marginally significant; however, these stocks experience a considerable (nearly 100\%) increase in effective and quoted spreads following the switch. The authors are unable to provide an explanation for these seemingly contradictory results.

\section{Recent Switches from the NYSE to Nasdaq}

As noted, prior to 2000 there were no voluntary changes of exchange listings from the NYSE to the Nasdaq. On February 17, 2000, Aeroflex, Inc. became the first company to make the move on its own volition. In a case study of the Aeroflex switch, Kalay and Portniaguina (2001) report that the firm's move to Nasdaq resulted in significant positive abnormal returns, a lower bid/ask spread and an increase in daily trading volume. In a similar study on Aeroflex's move, Pruitt, Van Ness and Van Ness (2002) also document a significant lower bid/ask spread but they also find significant degradations in the number 
of equity trades. Overall, they find no improvements in trading or quoting behavior as a result of Aeroflex's move from the NYSE to Nasdaq.

In concurrent research similar to ours, Dang, Michayluk and Pham (2018) examine 53 firms that switch from the NYSE to Nasdaq from 2000-2015 and find that although long-term trading volume significantly increases, trading costs are higher meaning liquidity decreases, and that visibility proxied by media coverage and media sentiment increases. Since market structure determines how volume is reported, meaningful comparisons between NYSE and Nasdaq volume cannot be made and, consequently, we do not examine changes in trading volume. ${ }^{8}$ Like Dang et. al., we find that liquidity decreases following the switch from the NYSE to Nasdaq, as evidenced by significant increases in bid/ask spreads and relative spreads compared to their matched peer firms. However, regarding visibility, using media coverage and media sentiment to proxy for visibility, Dang et. al. report a significant increase in firm/stock visibility subsequent to the exchange switch; meanwhile, using analyst coverage, number of institutional shareholders and the percentage of shares held by institutions to proxy for visibility, we document no significant changes in visibility. Additionally, we use a predictive model, based on financial and stock characteristics, to determine the propensity or probability that a firm is listed on Nasdaq versus the NYSE and our matched sample is based on this propensity. Thus, we match each firm that actually switches from the NYSE to Nasdaq with the NYSE firm in their industry which has the closest probability of being a Nasdaq firm to the switch firm. Dang et. al., on the other hand, match firms based on market capitalization and stock prices. Like Dang et. al., we find that the switching firms are larger than the typical Nasdaq firms, but we are also able to show (based on propensity score) that these switching firms are more like NYSE firms than Nasdaq firms on a host of financial dimensions. We also show that more than 73 percent of these switch firms switched to Nasdaq highest tier, whose listing requirements are even more stringent than those of the NYSE and that there are no industry clientele effects motivating the switch. In addition, we show that although the market reacts somewhat positively to the announcement of the switch, there is no evidence of long-run abnormal stock performance nor any evidence of any operating performance improvements. Overall, there appears to be little economic incentive or disincentive to switch from the NYSE to Nasdaq.

\section{Other Factors that Could Motivate a Switch from the NYSE to Nasdaq}

There are several recent developments that could have hastened or encouraged voluntary switches from the NYSE to Nasdaq.

\section{Order Handling Rules}

Given the tremendously negative publicity Nasdaq received over the allegations of market-maker collusion as shown in Christie and Schultz (1994), the SEC and Nasdaq instituted a number of reforms concerning order handling rules (OHR). These OHR changes include the Limit Order Display Rule requiring that limit orders be made public when they are better than quotes posted by market makers. This new rule allows the general public to compete directly with Nasdaq market makers in setting bids and offers. Another change is the Quote Rule, which requires all market makers to publicly display their most competitive quotes, which had previously been posted only on electronic communication networks and not generally made available to the public. In addition, on June 2, 1997, the tick size on Nasdaq changed from $1 / 8$ to $1 / 16$ for all stocks with a price greater than $\$ 10$. After these market reforms, Barclay, Christie, Harris, Kandel and Schultz (1999) report that the spreads of Nasdaq-listed firms fell dramatically, though Bessembinder (1999) and Chung, Van Ness and Van Ness $(1999,2001)$ demonstrate that the spreads of Nasdaq firms are still greater than those of comparable NYSE firms. Nonetheless, these rule changes may have mitigated the real or perceived liquidity advantage of the NYSE.

\section{Repeal of Rule 500}

As previously mentioned, at one time the NYSE made it difficult to voluntarily de-list. NYSE Rule 500 required that in order to delist its securities, a company must obtain approval of two-thirds of its shareholders with not more than $10 \%$ of the shareholders objecting to the delisting, delay delisting for 20 
to 60 business days from the date of the written notice or the press release, provide actual written notice to at least its 35 largest shareholders of record and issue a press release announcing the delisting proposal and obtain the approval of the issuer's board of directors and its audit committee.

In the mid-1990s, the NYSE began to suspect that Rule 500 was a deterrent to some firms listing on the NYSE in the first place, so in 1997, it relaxed the rule such that a firm must obtain only board approval and notification of the 35 largest shareholders. In November 2003, the SEC forced the repeal of Rule 500 and today approval of the firm's board is the only requirement for delisting from any exchange.

\section{Symbol Portability}

Securities listed on Nasdaq have historically traded using four-character and sometimes five-character ticker symbols, while the practice of the NYSE is to list companies using one-, two- and three-character ticker symbols. Some NYSE-listed symbols are seen as important, prestigious, and sometimes whimsical elements of the companies' identities. ${ }^{9}$ As reported by Reuters, November 7, 2008, Nasdaq argued that several NYSE-listed companies had considered switching to Nasdaq from the NYSE, but chose not to do so due to the lack of portability of their ticker symbols. ${ }^{10}$ In November 2008, however, the SEC approved a Nasdaq's proposal that if a firm transfers its listing to another exchange, the new exchange would automatically have the right to use that symbol.

\section{Nasdaq's Three-Tier Market Classification}

Prior to July 2006, Nasdaq listings were organized into two tiers: an upper-tier called the Nasdaq National Market and the other called the Nasdaq SmallCap Market. The initial listing requirements for the former were more stringent than for the latter, which was primarily designed as a market for raising capital.

In July 2006, Nasdaq introduced a three-tier market initiative. The top-tier, the Nasdaq National Market, was split into two different tiers, the Nasdaq Global Select Market and the Nasdaq Global Market, while the lower-tier, the Nasdaq SmallCap Market, was renamed the Nasdaq Capital Market. The Nasdaq Global Select Market has the most stringent listing requirements of the tiers and is designed to highlight the most prestigious firms. The initial listing requirements of the Global Select Market are more stringent than even those of the NYSE, and more than 73 percent of the firms switching from the NYSE move to this highest tier. ${ }^{11}$ The initial listing requirements of the remaining two tiers remain the same as before and are not as stringent as those of the NYSE. ${ }^{12}$ The Nasdaq Capital Market has the most lenient listing requirements. The continued listing requirements and listing fees of Nasdaq's highest tier are similar to those of the middle tier. ${ }^{13}$ Listing fees for all three Nasdaq tiers are lower than the NYSE listing fees, so at the very least, a switch can result in a reduction in fees, but the amounts of the fees are relatively small for a publicly traded company, so fees are unlikely to be a stimulant or a deterrent. Nasdaq also states that companies listed on the highest tier receive an enhanced package of services from Nasdaq to support these companies in communications, visibility, management, and board support, but as with fees, these services are unlikely to motivate a switch.

\section{Listing Requirements}

The NYSE and the Nasdaq initial and continuing listing requirements are provided in Appendix 1 and the listing fees for each exchange are provided in Appendix 2. The listing requirements of exchanges play a certifying role to outside investors, increasing transparency and mitigating information asymmetry. Lin and Liao (2015) suggest that higher listing requirements work as an effective mechanism to restrain managers from providing lower-quality financial reports, which leads to better long-run post-listing stock and operating performance.

Given the certification value of listing standards, stock exchanges are likely to use the choice of standards as a competitive tool to retain and attract more listings. Yet in setting its listing requirements, an exchange faces a trade-off between its own current performance and its future performance. Exchanges are accountable to their owners with respect to performance, and most exchanges are themselves publicly traded companies. Low listing standards can attract more listings and improve current performance, but 
they can also affect the exchange's reputation, potentially deterring future listings which increases the probability of poor future performance (Chemmanur, He and Fulghieri (2008)). Nasdaq's three market tiers are a possible solution to this trade-off problem and potentially mitigates the lemon problem faced by many firms currently listed on Nasdaq and firms considering switching to Nasdaq. Hence, the certification benefit of the NYSE has undoubtedly weakened.

\section{Liquidity and Trading Costs}

Liquidity is often measured by bid-ask spreads, but actual trading costs can differ and are notoriously difficult to measure. In general, the higher the bid-ask spreads, the lower the liquidity and the higher the trading costs. As suggested by Aggarwal and Angel (1998), however, large institutional investors have the ability to trade amongst themselves through a variety of electronic markets, bypassing the dealer market with its higher bid-ask spreads. Since the Nasdaq bid-ask spread does not represent the true trading costs for institutional investors, we cannot estimate the true change in trading costs associated with a move to Nasdaq. Many studies have examined whether the NYSE or Nasdaq provides more liquidity advantage, results are mixed but evidence of higher spreads on Nasdaq seem to be more dominant.

Chung, Van Ness, and Van Ness (2004) find that the spreads of Nasdaq stocks are higher when spreads are equally weighted across stocks, but the spreads of NYSE stocks are higher when spreads are volume weighted. Reinganum (1990) finds that Nasdaq appears to have a liquidity advantage over the NYSE for small firms but not for large companies. On the other hand, Chou (2005) finds that the liquidity for smaller firms on these two exchanges are no longer significantly different after controlling for economic variables likely to affect spread sizes.

As mentioned above, however, evidence of higher spreads on Nasdaq than on the NYSE have been more dominant. Huang and Stoll (1996) examine Nasdaq and NYSE firms for the entire year of 1991 and find that transaction costs measured by spreads are twice as large for a sample of Nasdaq stocks as they are for a matched sample of NYSE stocks. Consistently, several other studies find that spreads are larger for Nasdaq-listed than for NYSE-listed stocks not only before but also after the market reforms following Nasdaq's scandal in 1994 despite the fact that the reforms have improved competition on Nasdaq and greatly reduced the differences in spreads between the two exchanges. (Bessembinder and Kaufman (1997ab), Bessembinder (1999), Schultz (2000), Weston (2000), and He and Wu (2003)). Consequently, firms with excessively high bid-ask spreads tend to move from Nasdaq to the NYSE (Cowan, Carter, Dark, and Singh (1992)) and spreads for stocks that voluntarily switch from Nasdaq to the NYSE or AMEX fall significantly (Christie and Huang (1994)). Although these studies are all prior to the year 2004, they are consistent with our findings, which cover the period from 2000-2013, and show a significant increase in spreads for firms that voluntarily switch from the NYSE to Nasdaq. It, thus, may seem puzzling that companies appear to switch from a lower spread environment to a higher spread environment, but it is entirely possible that companies care little about the spreads on their shares, as suggested by Aggarwal and Angel (1998).

Besides bid-ask spreads, some other papers measure trading costs using block trades or price impact of the trades and commissions, etc. Similar to studies using bid-ask spreads, studies using other trading cost measures provide mixed results but evidence showing higher trading costs on Nasdaq than on the NYSE still seems stronger. Chan and Lakonishok (1997) look at execution costs defined as price impact plus commission costs for trade packages for institutional investors and find that execution costs are lower on Nasdaq for trades in smaller firms and lower on the NYSE for larger stocks. ${ }^{14}$ Their results, however, are sensitive to the time period chosen, as other studies consistently show that trading costs are higher on Nasdaq than they are on the NYSE. Also using broker commissions and price impact of the trade but with a different data set, Keim and Madhavan (1997) show that institutional trades in NYSElisted stocks have lower trading costs than in comparable Nasdaq stocks. Similarly, using three other trading cost measures - the frequencies of the sizes and types of block trades found in the two markets, the immediate price effects of the block transactions, and the temporary and permanent price effects of the 
blocks, LaPlante and Muscarella (1997) also conclude that the NYSE provides more liquidity for block transactions.

\section{DATA AND SAMPLE DESCRIPTION}

Our objective is to examine the 49 firms that voluntarily switched from the NYSE to Nasdaq to determine why they switched and if they ultimately realized any economic benefits. We identify these firms from the Nasdaq website and from changes in the exchange listing flag included in the Center for Research in Securities Prices (CRSP) database. We then identify whether the move was voluntary or involuntary by searching the LexisNexis Academic database for the original announcement, and we drop the involuntary switches. ${ }^{15}$ Panel A of Appendix 3 lists the firms and the dates on which they announced the switch and the date the stock began trading on Nasdaq. ${ }^{16}$

In Table 1 we present the distribution of firms voluntarily moving from the NYSE to Nasdaq by year for the period from 1973 through 2013. The number of firms voluntarily moving from the NYSE to Nasdaq is reported in Column 2. For comparative purposes, in Column 3 we also report the number of firms that moved involuntarily and in Column 4, the number of firms that moved from Nasdaq to the NYSE. As stated earlier, no firms voluntarily moved from the NYSE to Nasdaq prior to 2000 and a voluntary move was quite rare prior to 2008. Beginning in 2008, it became relatively more common for firms to voluntarily move from the NYSE to Nasdaq, with 40 of the 49 firms moving after that point. The number of switches peaked in 2009 when 10 firms moved from the NYSE to Nasdaq. While the number of moves from the NYSE to Nasdaq increased over the 2008-2013 period, moving from Nasdaq to the NYSE remained more common, as 66 firms moved their listings from Nasdaq to the NYSE between 2008 and 2013.

TABLE 1

FREQUENCY OF FIRMS CHANGING STOCK EXCHANGES FROM 1973-2013.

\begin{tabular}{lccc}
\hline Year & $\begin{array}{c}\text { Voluntary NYSE-to- } \\
\text { Nasdaq Transfers }\end{array}$ & $\begin{array}{c}\text { Involuntary NYSE-to } \\
\text { Nasdaq transfers }\end{array}$ & $\begin{array}{c}\text { Total Nasdaq-to- } \\
\text { NYSE transfers }\end{array}$ \\
\hline Prior to 2000* & 0 & 83 & 1,051 \\
2000 & 1 & 2 & 25 \\
2001 & 0 & 1 & 31 \\
2002 & 0 & 3 & 45 \\
2003 & 0 & 0 & 19 \\
2004 & 1 & 4 & 9 \\
2005 & 2 & 4 & 5 \\
2006 & 4 & 2 & 12 \\
2007 & 1 & 3 & 10 \\
2008 & 6 & 6 & 7 \\
2009 & 10 & 1 & 4 \\
2010 & 4 & 2 & 15 \\
2011 & 8 & 1 & 16 \\
2012 & 5 & 7 & 16 \\
2013 & 7 & 6 & 8 \\
\hline Total & 49 & 125 & 1,273 \\
\hline Covers the & 1 & &
\end{tabular}

*Covers the period 1973-2000 


\section{TABLE 2 \\ FAMA-FRENCH 10-INDUSTRY BREAKDOWN FOR 49 FIRMS THAT VOLUNTARILY TRANSFER EXCHANGE LISTING FROM THE NYSE TO NASDAQ, 2000-2013}

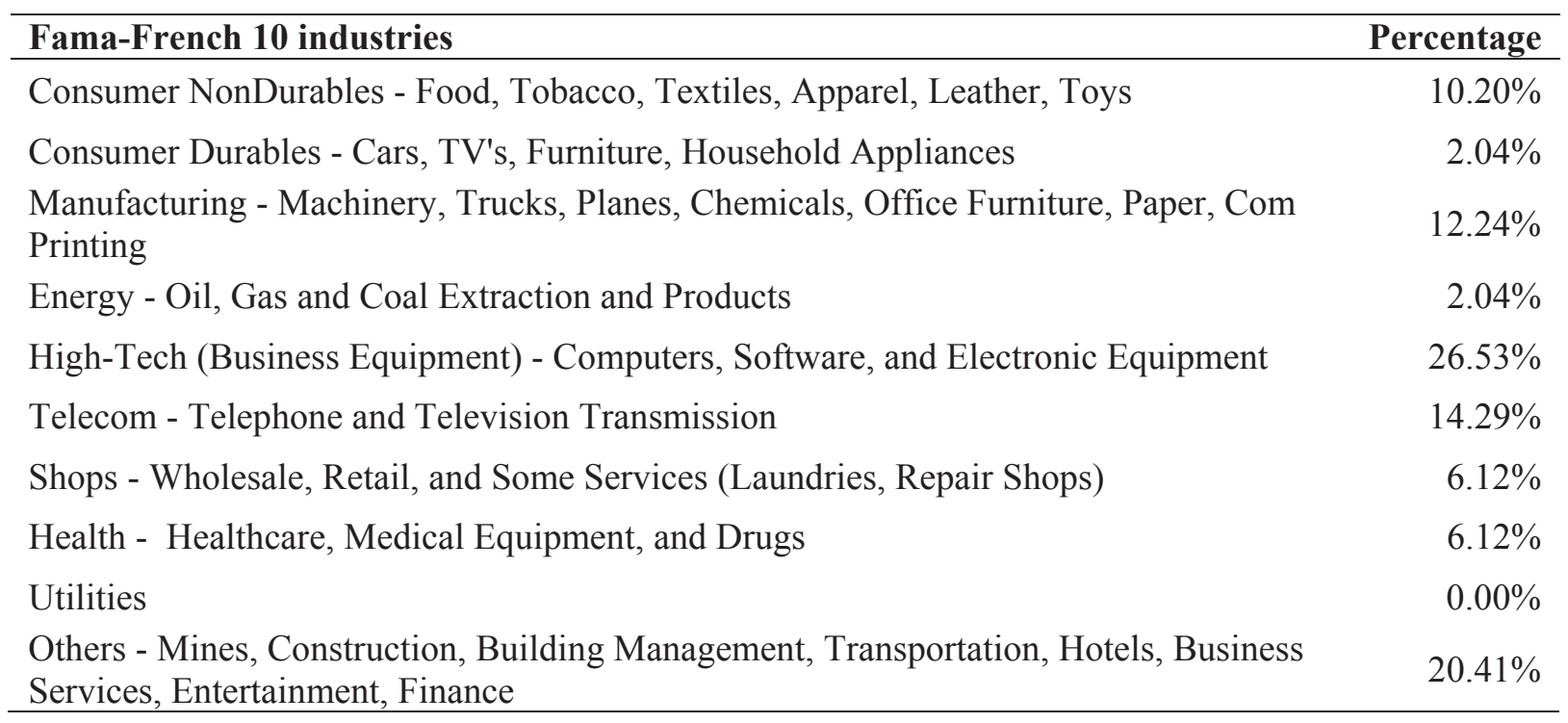

In Table 2, we provide the industry breakdown of the 49 firms that voluntarily transferred their listing from NYSE to Nasdaq, using the Fama-French 10-industry classification. Nasdaq is well-known for the tech companies they have listed and, as might be expected, two of the three top industries of switching firms are high-tech and telecom. The "Other" category, consisting of mines, construction, building management, transportation, hotels, business services, entertainment, and finance is the second largest group.

Although the firms switching from the NYSE to Nasdaq represent a variety of industries, there initially appears to be some industry clustering in high tech. This phenomenon could be evidence of a clientele effect, whereby a company switches because it perceives that most of its industry competitors are in Nasdaq. To examine this possibility, we calculate the percentage of the firms in the switching firm's industry that are already listed on Nasdaq. We also calculate the percentage of total industry market capitalization and sales accounted for by firms listed on Nasdaq in the year prior to the announcement of the exchange change. For slightly more than half of the firms that switch to Nasdaq (26 of 49), the majority of the firms in their respective industries are already listed on Nasdaq with the mean and median percentages at $57.6 \%$ and $55.7 \%$, respectively. This finding is not particularly remarkable, however, in that $53.6 \%$ of all firms are on Nasdaq. Hence, our finding that switching firms are in industries in which about $58 \%$ of the firms are listed on Nasdaq is not particularly unusual or unexpected, as a similar percentage of all firms are listed on Nasdaq. 


\section{FIGURE 2}

NASDAQ'S TIER BREAKDOWN OF YEARLY VOLUNTARY SWITCHES

FROM THE NYSE TO NASDAQ, 2000 - 2013

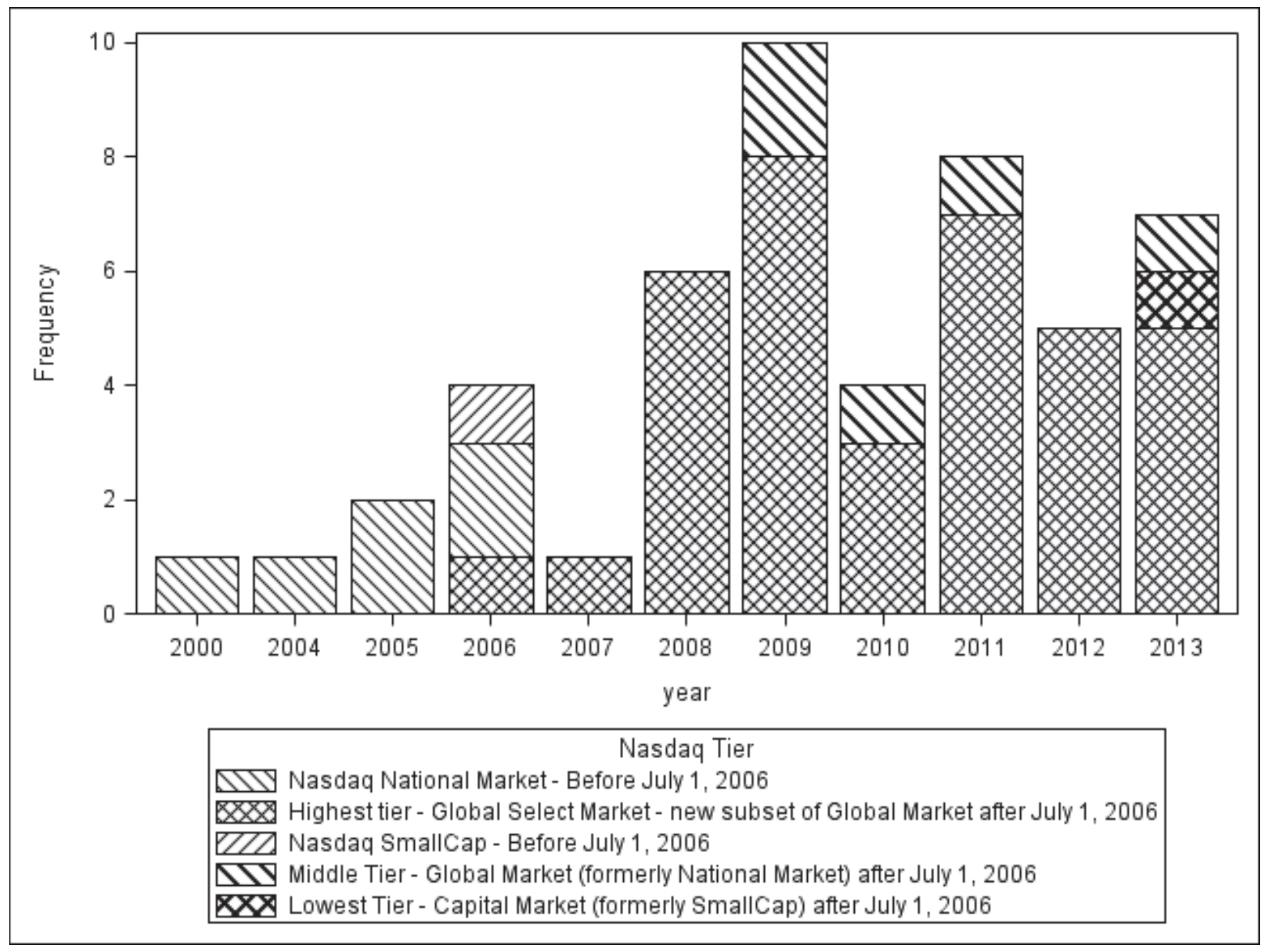

28 Journal of Accounting and Finance Vol. 19(7) 2019 
FIGURE 3

\section{RATIO OF NEW YORK STOCK EXCHANGE FIRM TO NASDAQ FIRM WITH RESPECT TO MEAN AND MEDIAN SIZE AND AGE, AND MEAN RATIO OF DIVIDEND \\ YIELD, 2000 - 2013}

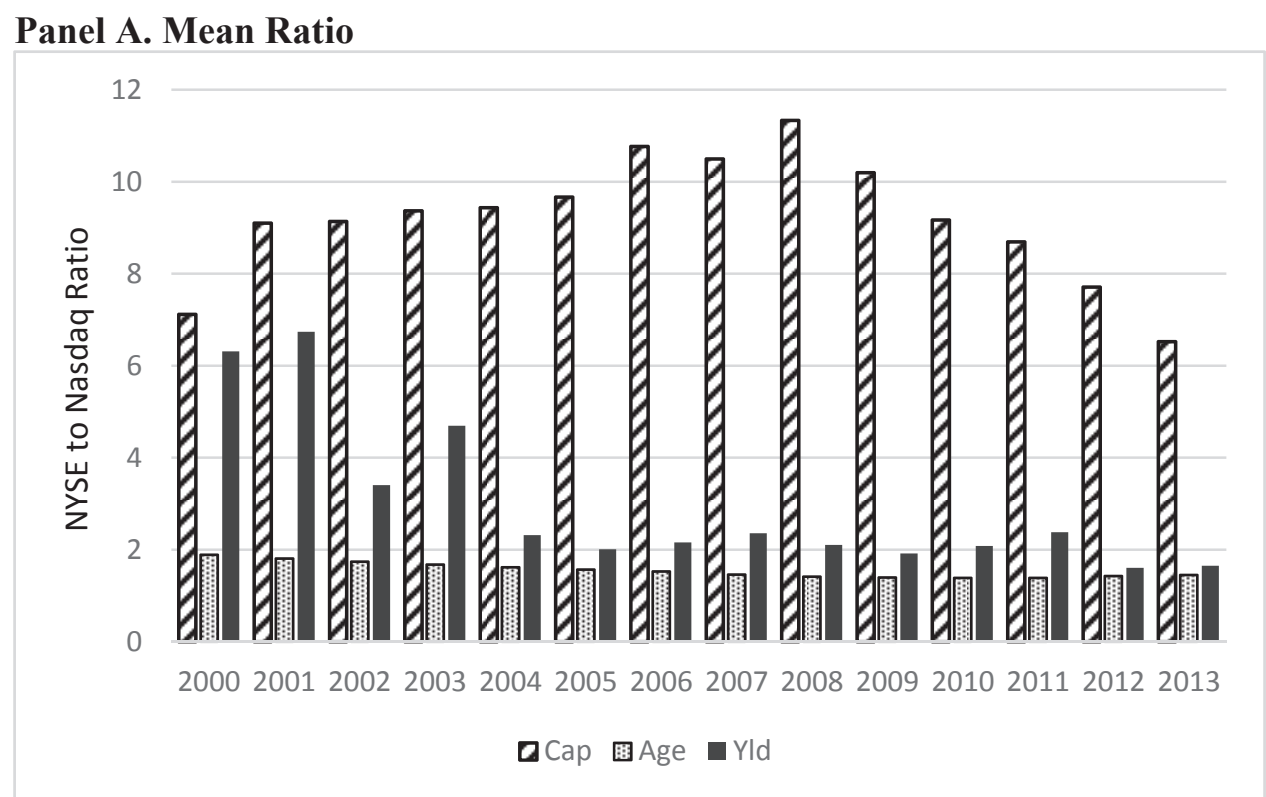

Panel B. Median Ratio

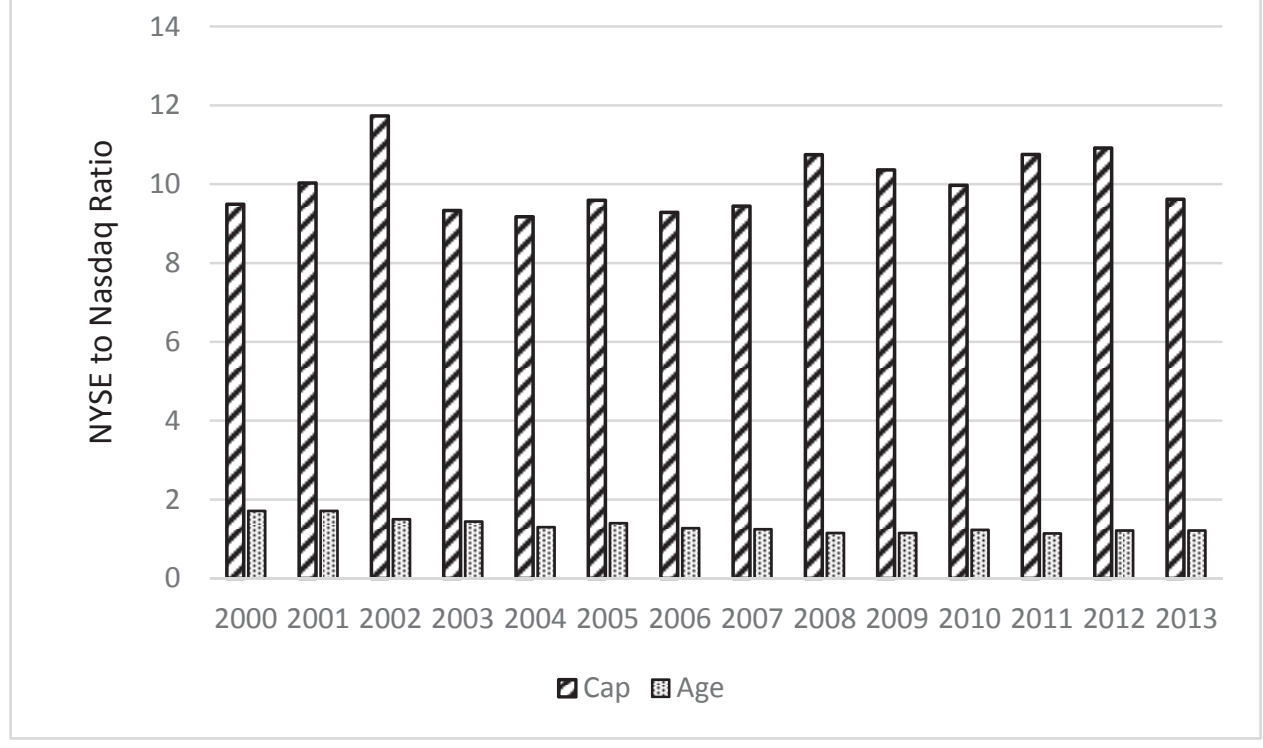

We also find that their Nasdaq industry peers account for an average of about $23 \%$ of industry capitalization and about $20 \%$ of industry sales in the prior year. Thus, their Nasdaq peers are a relatively high percentage of total firms, but account for lower market value and lower sales. For all firms, the mean market capitalization of Nasdaq firms is about $11.4 \%$ and Nasdaq firms account for a mean of $12.5 \%$ of all sales. Thus, the Nasdaq industry peers they are joining have greater sales and market cap than the across-the-board average for Nasdaq firms relative to NYSE firms. So, it appears the firms they are 
joining are the industry leaders, suggesting that there may be a modest clientele effect for firms wanting to be perceived as an industry leader and to be listed where their industry leaders are listed.

As previously discussed, in 2006 Nasdaq was reorganized into three tiers with different listing requirements and fees. ${ }^{17}$ Prior to 2006, Nasdaq-listed firms were divided into the Nasdaq National Market and the Nasdaq SmallCap Market, but in mid-2006 the old Nasdaq National Market became known as the Nasdaq Global Market with an elite subset classified into the Nasdaq Global Select Market. The Nasdaq SmallCap Market became known as the Nasdaq Capital Market. Forty-two of the 49 switching firms moved into the highest Nasdaq tier available at the time. Thirty-six firms moved into the Nasdaq Global Select Market and six moved into the Nasdaq National Market, which was the highest tier available prior to 2006. Five firms moved into the middle tier, the Nasdaq Global Market, and one firm each moved into the Nasdaq SmallCap Market and the Nasdaq Capital Market.

The breakdown among the three Nasdaq tiers to which NYSE firms switch is provided by year in Figure 2. Before the three-tier system was introduced in 2006, seven firms switched from the NYSE to Nasdaq, but only one, Computer Task Group Inc., switched to the lower of the two tiers in place at that time, and it has since moved to the middle tier and then on to the highest tier. After 2006, the majority of firms that originally moved to the higher tier moved to the Nasdaq Global Select Market, where listing requirements are even more stringent than those of the NYSE. Only one firm, Community Bankers Trust Corp, switched from the NYSE to Nasdaq's lowest tier, the Nasdaq Capital Market, where it remains to this day. The remaining (four) firms switched to Nasdaq's middle tier, the Nasdaq Global Market.

One reason fewer firms are switching from Nasdaq to the NYSE and an increasing number of firms are switching from the NYSE to Nasdaq could be that some differences between the exchanges and firms listed on the exchanges are diminishing. There may be far less of a psychological barrier to jumping from the NYSE to Nasdaq if the apparent differences are declining. Figure 3 shows the time series of the ratio of market capitalization, age and dividend yield of NYSE firms relative to Nasdaq firms. We show the mean ratios in Panel A and median ratios for market capitalization and age in Panel B; we cannot calculate the ratio of dividend yields as median dividend yield for Nasdaq firms is zero in every year. As shown in Panel A, at the beginning of our sample, the mean market capitalization of NYSE firms was about seven times that of Nasdaq firms, rose to about 11 times in 2008 and returned to about seven by the end of our sample in 2013. The average age ratio has fallen steadily from around 1.89 to about 1.45 . The most notable change has been the average ratio of yields, which has declined from about 6.3 to about 1.65. In Panel B, the median ratio for market cap and age has behaved similarly. As noted, we cannot compute a ratio for dividend yield since the Nasdaq median is $0.0 \%$. The NYSE average yield was at $0.84 \%$ at the beginning of the sample, rose to a peak of $2.1 \%$ in 2008 and in 2013 was $1.31 \%$. Thus, over time the differences between the firms listed on the NYSE and those listed on Nasdaq in terms of age and dividend yield have faded, though the NYSE still maintains a decided edge in the size of firms. As the differences between the exchanges decrease, firms might perceive less advantage to remaining on the NYSE. Nevertheless, it is important to note that these similarities are far more likely to be an effect than a cause.

Of course, there are many reasons one can come up with as to why companies might switch. We now look at what the companies themselves say about why they switched. We read the press releases and in 45 of 49 cases, the companies provide at least one reason why they switched. In 27 cases, the companies refer to Nasdaq being more cost effective without sacrificing the quality of trading execution or liquidity. Thus, in $60 \%$ of the switches, the companies state that they were saving money. In 12 cases, the companies cite improvements in visibility and exposure through Nasdaq's marketing. Eight times the companies indicate that the reason was to maintain and enhance trading liquidity, and another eight times, the companies cite Nasdaq's advanced systems. Six times the companies mention being aligned with tech peers, and another six times the companies say that Nasdaq was the leading exchange for growth-oriented companies. Four times the companies mention the multiple market maker system of Nasdaq, and three times the companies refer to Nasdaq's product offerings. Eight other reasons are mentioned either twice each or only once. 
In addition, Nasdaq itself provides some reasons that are mentioned in these press releases. It specifically states that it provides companies with global visibility, innovation, high listing standards, and it claims to be a market for leaders in various industries.

We also verify through Compustat variables that the exchange on which the stock is listed is the one on which the majority of its trading volume occurs. Hence, there is no reason to believe that a stock switched its listing because the majority of its shares were trading on Nasdaq.

\section{RESULTS}

Our primary objectives are to examine the benefits of switching stock listings from the NYSE to Nasdaq. If we perceive benefits, then Nasdaq would have gained the upper hand. If there is a net loss, then the NYSE is still the leader. If there are no perceived benefits, then the two exchanges are relatively equivalent, and it would appear not to matter what exchange a firm is listed on.

\section{Multivariate Analysis of Firms Listed on the NYSE Relative to Firms Listed on Nasdaq}

In Table 3, we report the results of a multivariate analysis that has the objective of determining whether the switching firms are more like the firms they leave or the firms they join. If they are more like the firms they join than the firms they leave, it could provide a reason for the move.

In the first step, we build an explanatory model that forms a multivariate profile of NYSE and Nasdaq firms. The model is a logit regression with 1 as the dependent variable if the firm is listed on Nasdaq and 0 if it is listed on the NYSE. For the NYSE sample, we use all firms other than the switch firms over the period 2000-2015. Although the switch sample goes through only 2013, we will ultimately make predictions that require two additional years. To verify the reliability of the model, we determine the average predicted probabilities for the in-sample NYSE and Nasdaq firms.

We utilize the following independent explanatory variables: log assets, log age, dividend yield, ROE, leverage, asset tangibility, previous year average return, previous year return volatility, $\mathrm{M} / \mathrm{B}$, cash to assets, trading costs/ liquidity proxies (quoted and relative spreads), visibility proxies (number of institutional investors, percentage of shares held by institutional investors and number of analysts following) and industry effect proxies (percentage of industry on Nasdaq by number of firms, market capitalization and sales). We also include year and industry fixed effects. ${ }^{18} \mathrm{R} \& \mathrm{D}$ is excluded, as it would cause the loss of 17 of the 49 observations. Three regressions are conducted, one with percentage of industry on Nasdaq by sales dropped, one with percentage of industry on Nasdaq by market capitalization dropped, and one with number of institutional investors and percentage of industry on Nasdaq by sales dropped; these three exclusions are done to mitigate multicollinearity.

The second step of the process is to insert the variable values for the switching firms into the model to arrive at a predicted probability of membership of a given exchange. The model is built using 52,540 firm-year observations. As a useful comparison, we determine these predicted probabilities for all nonswitching firms and report the average across firms.

The regression results are provided in Panel A. The numbers reported for each variable are the average marginal effects with the odds ratios in parentheses. A high level of significance is obtained for most of the variables, and the Tjur $\mathrm{R}^{2}$, a measure roughly comparable to an ordinary least squares regression $\mathrm{R}^{2}$, is strong at around $42 \%$.

Panel B shows that all three models produce an average predicted value of about $75 \%$ for Nasdaq firms and 33\% for NYSE firms, suggesting that the model has strong discriminatory power. In other words, taking the data for a randomly chosen Nasdaq firm and inserting it into the model produces an expected probability of that firm being a Nasdaq firm of $75 \%$. Doing the same for an NYSE firm chosen at random produces an expected probability of that firm being a Nasdaq firm of $33 \%$. Thus, this model discriminates quite well in identifying Nasdaq and NYSE firms. This result is particularly impressive in that the differences between the Nasdaq and NYSE firms have narrowed somewhat over the years.

Panel $\mathrm{C}$ shows the average predicted values for the switching firms for the models measured at the year of the switch, one year after the switch, and two years after the switch. These results show the 
likelihood of a switching firm fitting the profile of a Nasdaq firm. Of course, these firms are not Nasdaq firms, but they can still be more like Nasdaq firms than like NYSE firms. All three models give similar results. The average probability that the switch firm is a Nasdaq firm is around $42 \%$ at the year of the switch, $43 \%$ and $42 \%$ one and two years after the switch, respectively. Thus, there is only a roughly $42 \%$ likelihood that the switching firm is a Nasdaq firm and this difference varies little over the following two years. In other words, the switching firms are more like the firms they leave than the firms they join, and they do not become more like Nasdaq firms in the next two years.

In Panel D, we show the average predicted probabilities of the switching firms that moved to the highest tier being like Nasdaq firms. As one might expect, these firms are probably less likely to be like a typical Nasdaq firm, and indeed, that is true. Their probabilities are all around $29 \%$ at the time of the switch and up to two years later. Thus, these highest-tier firms are not much like Nasdaq firms.

In Panel E, we show the average predicted probabilities of the firms that move to one of the lower two Nasdaq tiers. These firms are more likely to be like Nasdaq firms, and indeed, the average probability is about $79 \%$ at the time of the switch and one and two years after the switch. In other words, these firms that switched to the Nasdaq lower tiers were indeed more like Nasdaq firms than NYSE firms. Essentially, firms switching to the highest Nasdaq tiers appear more like NYSE firms, while firms switching to the lower tiers appear more like Nasdaq firms.

\section{TABLE 3 \\ NYSE VERSUS NASDAQ: MULTIVARIATE LOGISTIC REGRESSION FOR ALL NASDAQ TIERS}

The first step is the estimation of the model coefficients using a logistic regression with the dependent variable being 1 if a firm is listed on Nasdaq and 0 if it is listed on the NYSE for all firms other than the switch firms in the period from 2000 to 2015, and we include year and industry fixed effects. The parameters shown below are the average marginal effects over all observations, which reflect the changes in the predicted probability for a one unit change in the respective variables. The odds ratios are in parentheses. Odds ratios less (greater) than 1 indicate a negative (positive) marginal effect. The second step is to insert the values of the independent variables for the switch firms into the estimated model to obtain a predicted probability of which exchange the firm is likely to belong. Predicted probabilities will be between 0 and 1 and will be closer to 1 if the firm is more like a Nasdaq firm and 0 if the firm is more like an NYSE firm. The Tjur $\mathrm{R}^{2}$ measures the absolute value of the difference between the means of the predicted probabilities and is a measure of the in-sample accuracy of the model.

Panel A. Regression results

\begin{tabular}{llll}
\hline & \multicolumn{1}{c}{ I } & \multicolumn{1}{c}{ II } & \multicolumn{1}{c}{ III } \\
\hline Parameters & \multicolumn{1}{c}{ Average Marginal Effects and } & Odds Ratios (in parentheses) \\
Log Assets & $-0.1010^{* * *}$ & $-0.1012^{* * *}$ & $-0.1029^{* * *}$ \\
& $(0.4924)$ & $(0.4920)$ & $(0.4859)$ \\
Log Age & $-0.0560^{* * *}$ & $-0.0562^{* * *}$ & $-0.0579^{* * *}$ \\
& $(0.6752)$ & $(0.6746)$ & $(0.6664)$ \\
Dividend Yield & $-0.3328^{* * *}$ & $-0.3338^{* * *}$ & $-0.3323^{* * *}$ \\
& $(0.0969)$ & $(0.0964)$ & $(0.0972)$ \\
ROE & $-0.0028^{* * *}$ & $-0.0028^{* * *}$ & $-0.0028^{* * *}$ \\
& $(0.9808)$ & $(0.9806)$ & $(0.9807)$ \\
Leverage & $-0.1231^{* * *}$ & $-0.1226^{* * *}$ & $-0.1223^{* * *}$ \\
& $(0.4219)$ & $(0.4232)$ & $(0.4241)$ \\
Asset Tangibility & $-0.2243^{* * *}$ & $-0.2252^{* * *}$ & $-0.2246^{* * *}$ \\
& $(0.2074)$ & $(0.2062)$ & $(0.2070)$ \\
Previous Year Average & $-0.0739^{* * *}$ & $-0.0726^{* * *}$ & $-0.0759^{* * *}$ \\
Return & $(0.5954)$ & $(0.6013)$ & $(0.5874)$ \\
Previous Year Return & $0.0887^{* * *}$ & $0.0853^{* * *}$ & $0.0932^{* * *}$ \\
Volatility & $(1.8628)$ & $(1.8178)$ & $(1.9223)$
\end{tabular}




\begin{tabular}{|c|c|c|c|}
\hline $\mathrm{M} / \mathrm{B}$ & $\begin{array}{l}-0.0191 * * * \\
(0.8749)\end{array}$ & $\begin{array}{l}-0.0189 * * * \\
(0.8757)\end{array}$ & $\begin{array}{l}-0.0195^{* * *} \\
(0.8721)\end{array}$ \\
\hline Cash over Assets & $\begin{array}{l}0.0444 * * * \\
(1.3649)\end{array}$ & $\begin{array}{l}0.0434 * * * \\
(1.3557)\end{array}$ & $\begin{array}{l}0.0429 * * * \\
(1.3513)\end{array}$ \\
\hline Quoted Spread & $\begin{array}{l}0.0182 * * * \\
(1.1366)\end{array}$ & $\begin{array}{l}0.0192 * * * \\
(1.1436)\end{array}$ & $\begin{array}{l}0.0189 * * * \\
(1.1421)\end{array}$ \\
\hline Relative Spread & $\begin{array}{l}0.0003 * * * \\
(1.0022)\end{array}$ & $\begin{array}{l}0.0003 * * * \\
(1.0021)\end{array}$ & $\begin{array}{l}0.0003 * * * \\
(1.0022)\end{array}$ \\
\hline $\begin{array}{l}\text { Number of institutional } \\
\text { investors }\end{array}$ & $\begin{array}{l}-0.0001^{* * *} \\
(0.9996)\end{array}$ & $\begin{array}{l}-0.0001^{* * *} \\
(0.9996)\end{array}$ & \\
\hline $\begin{array}{l}\text { Percentage of shares held } \\
\text { by institutional investors }\end{array}$ & $\begin{array}{l}-0.0012 * * * \\
(0.9917)\end{array}$ & $\begin{array}{l}-0.0012 * * * \\
(0.9916)\end{array}$ & $\begin{array}{l}-0.0013 * * * \\
(0.9912)\end{array}$ \\
\hline Number of analysts & $0.0034 * * *$ & $0.0035^{* * *}$ & $0.0029 * * *$ \\
\hline $\begin{array}{l}\text { following } \\
\% \text { Industry on }\end{array}$ & $\begin{array}{l}(1.0245) \\
0.5340 * * *\end{array}$ & $\begin{array}{l}(1.0245) \\
0.5382 * * *\end{array}$ & $\begin{array}{l}(1.0207) \\
0.5272 * * *\end{array}$ \\
\hline $\begin{array}{l}\text { Nasdaq by Number } \\
\text { of Firms }\end{array}$ & $(42.3005)$ & $(43.5060)$ & $(40.3221)$ \\
\hline$\%$ Industry on & $0.3286^{* * *}$ & & $0.3264 * * *$ \\
\hline $\begin{array}{l}\text { Nasdaq by Market } \\
\text { Capitalization }\end{array}$ & $(10.0172)$ & & $(9.8631)$ \\
\hline$\%$ Industry on & & $0.0333 * * *$ & \\
\hline Nasdaq by Sales & & $(1.2626)$ & \\
\hline Number of & 52,540 & 52,540 & 52,540 \\
\hline $\begin{array}{l}\text { observations } \\
\text { Tjur } \mathrm{R}^{2}\end{array}$ & 0.4172 & 0.4169 & 0.4170 \\
\hline
\end{tabular}

Panel B. In-sample test results: Average predicted probability of in-sample firms being a Nasdaq firm

Using models I, II and III above, we estimate the predicted probability of being a Nasdaq firm for each in-sample Nasdaq firm and each in-sample NYSE firm and report the averages in this panel.

\begin{tabular}{lccc}
\hline $\begin{array}{l}\text { Average predicted probability of being } \\
\text { Nasdaq firms for in-sample firms }\end{array}$ & I & II & III \\
\hline For Nasdaq firms & 0.7494 & 0.7493 & 0.7494 \\
For NYSE firms & 0.3323 & 0.3324 & 0.3323 \\
\hline
\end{tabular}

Panel C. Average predicted probabilities of switch firms being a Nasdaq firm

Using models I, II and III above, we estimate the predicted probability of each switch firm being a Nasdaq firm and report the averages in this panel.

\begin{tabular}{lccc}
\hline $\begin{array}{l}\text { Average predicted probability of being } \\
\text { Nasdaq firms for all switch firms }\end{array}$ & I & II & III \\
\hline At the year of the switch & 0.4248 & 0.4251 & 0.4257 \\
At the year one year after the switch & 0.4329 & 0.4330 & 0.4337 \\
At the year two years after the switch & 0.4225 & 0.4221 & 0.4240
\end{tabular}

Panel D. Average predicted probabilities of switch firms that moved to the highest tier being a Nasdaq firm

Using models I, II and III above, we estimate the predicted probability of being a Nasdaq firm for each of the 36 switch firms that switched to the highest tier and report the averages in this panel. 


\begin{tabular}{|c|c|c|c|}
\hline $\begin{array}{l}\text { Average predicted probability of being } \\
\text { Nasdaq firms for switch firms that } \\
\text { switched to the highest tier }\end{array}$ & I & II & III \\
\hline At the year of the switch & 0.2930 & 0.2941 & 0.2947 \\
\hline At the year one year after the switch & 0.2980 & 0.2990 & 0.2993 \\
\hline At the year two years after the switch & 0.2918 & 0.2918 & 0.2944 \\
\hline \multicolumn{4}{|c|}{$\begin{array}{l}\text { Panel E. Average predicted probabilities of switch firms that did not switch to the highest tier being } \\
\text { a Nasdaq firm } \\
\text { Using models I, II and III above, we estimate the predicted probability of being a Nasdaq firm for each of the } 13 \\
\text { switch firms that did not switch to the highest tier and report the averages in this panel. }\end{array}$} \\
\hline $\begin{array}{l}\text { Average predicted probability of being } \\
\text { Nasdaq firms for switch firms that did } \\
\text { not } \text { switch to the highest tier }\end{array}$ & $\mathrm{I}$ & II & III \\
\hline At the year of the switch & 0.7898 & 0.7879 & 0.7885 \\
\hline At the year one year after the switch & 0.8065 & 0.8041 & 0.8059 \\
\hline At the year two years after the switch & 0.7844 & 0.7829 & 0.7829 \\
\hline
\end{tabular}

In Table 4, we report the results from the same models restricted to only the firms in the Nasdaq highest tier. The dependent variable is set to 1 if the firm is in the Nasdaq highest tier and 0 if in the NYSE. Observations for the other Nasdaq tiers are omitted, leaving 32,971 observations. Thus, this model is a predictive model for discriminating between NYSE firms and Nasdaq highest-tier firms. As such, we should expect its predictive power to be a little weaker. Although the regression reported in Panel A has a Tjur $\mathrm{R}^{2}$ that is slightly lower, it is still quite respectable at about $36 \%$. The average in-sample probability reported in Panel B for Nasdaq highest tier firms is about 56\%, and for NYSE firms is about 20\%, results that indicate a relatively strong explanatory model. In other words, the model predicts that a Nasdaq highest-tier firm has a 56\% chance of being a Nasdaq highest tier firm and an NYSE firm has only a $20 \%$ chance of being a Nasdaq highest tier firm. The model is slightly weaker than when all Nasdaq firms are included, but that is to be expected: the differences in NYSE and Nasdaq highest-tier firms are smaller. The probability that the NYSE switching firms would be Nasdaq highest-tier firms, reported in Panel C, averages around 33\%. Thus, these highest tier firms are considerably more like NYSE firms. 
TABLE 4

NYSE VERSUS NASDAQ TOP-TIER: MULTIVARIATE LOGISTIC REGRESSION FOR NASDAQ HIGHEST TIER ONLY

A full description is provided in the caption to Table 4. Here we confine the sample to Nasdaq highest tier firms.

Panel A. Regression results

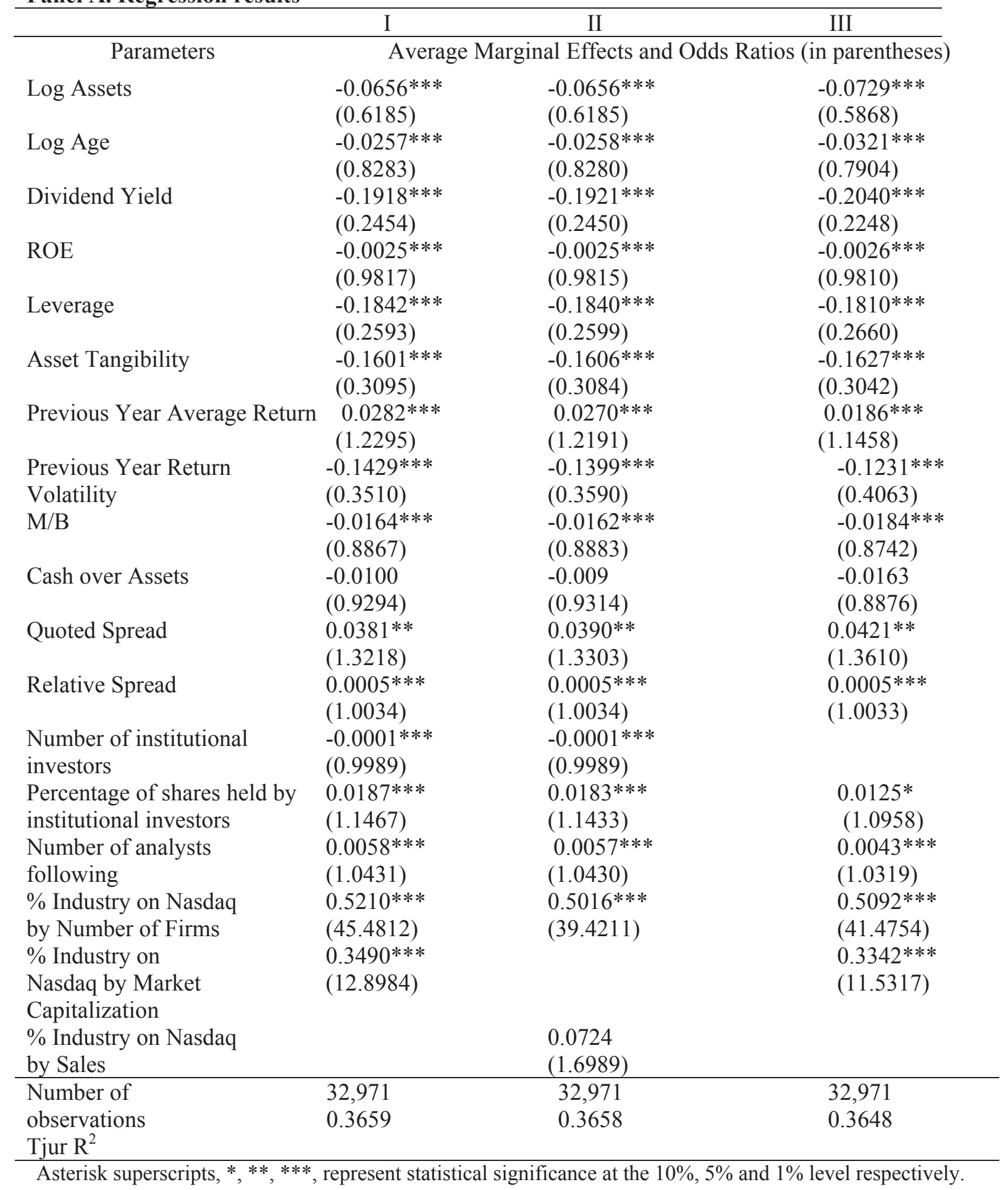




\section{Panel B. In-sample test results: Average predicted probability of in-sample firms being a Nasdaq}

highest tier firm

Using models I, II and III above, we estimate the predicted probability of being a Nasdaq highest tier firm for each in-sample Nasdaq highest tier firm and each in-sample NYSE firm and report the averages in this panel.

\begin{tabular}{lccc}
\hline $\begin{array}{l}\text { Average predicted probability of being Nasdaq highest tier } \\
\text { firms for in-sample firms }\end{array}$ & I & II & III \\
\hline For Nasdaq highest tier firms & 0.5656 & 0.5655 & 0.5648 \\
For NYSE firms & 0.1997 & 0.1997 & 0.2000 \\
\hline
\end{tabular}

Panel C. Average predicted probabilities of switch firms being Nasdaq highest tier firms

Using models I, II and III estimated above, we get the predicted probability of each switch firm that switched to Nasdaq highest tier being a Nasdaq highest tier firm and report the averages in this panel.

\begin{tabular}{lccc}
\hline $\begin{array}{l}\text { Average predicted probability of being Nasdaq highest tier } \\
\text { firms for switch firms that switched to the highest tier }\end{array}$ & I & II & III \\
\hline At the year of the switch & 0.3277 & 0.3278 & 0.3287 \\
At the year one year after the switch & 0.3368 & 0.3371 & 0.3370 \\
At the year two years after the switch & 0.3319 & 0.3310 & 0.3357 \\
\hline
\end{tabular}

In summary, the model predicts that switching firms are not leaving because they are more like firms on the Nasdaq than firms on the NYSE. In other words, they are not simply firms who feel they are on the "wrong" exchange.

\section{Market Reaction to the Switch Announcement}

Regardless of their reason for switching, these firms presumably anticipate a benefit to switching. We perform a simple event study to examine whether investors perceive a benefit to the switch to Nasdaq and report the results in Table 5. The market appears to react positively to the announcement of the switch from the NYSE to Nasdaq, but the response is not strongly significant. The three-day cumulative abnormal return (CAR) beginning the day prior to the announcement and ending the day after the announcement is $0.73 \%$ and is only statistically significant at the $10 \%$ level. We also report the CARs for a year prior to the announcement and a year following the announcement. The CARs observed prior to the announcement are positive, but insignificant, while the CARs observed following the announcement are initially positive, but negative after a year and insignificant. The market appears to be more or less ambivalent about the move; there may be a modest short-term response to the announcement, but little or no long-term effect. 


\section{TABLE 5 \\ ABNORMAL RETURNS AROUND THE ANNOUNCEMENT OF A SWITCH FROM THE NYSE TO NASDAQ}

The parameters of our market models are estimated over the period beginning 255 prior to the switch announcement and ending 61 days prior to the announcement. We use the value-weighted CRSP index as our proxy for market returns and market volume. We also perform the event study using an estimation period beginning 61 days following the announcement and ending 255 days after the announcement with qualitatively similar results.

\begin{tabular}{rrcc}
\hline Days & CAR(\%) & \# Positive: \# Negative & Patell Z \\
\hline$(-255,-2)$ & $1.11 \%$ & $28: 21$ & -0.248 \\
$(-59,-2)$ & $2.59 \%$ & $28: 21$ & 0.019 \\
$(-20,-2)$ & $1.82 \%$ & $24: 25$ & -0.286 \\
$(-1,1)$ & $0.73 \%$ & $27: 22$ & $1.470 *$ \\
$(2,20)$ & $0.27 \%$ & $23: 26$ & 0.395 \\
$(2,59)$ & $0.63 \%$ & $27: 22$ & 0.365 \\
$(2,255)$ & $-1.38 \%$ & $25: 24$ & 0.331 \\
\hline
\end{tabular}

Day 0 signifies the first public announcement of the move. Asterisk superscripts, $*, * *, * *$, represent statistical significance at the $10 \%, 5 \%$ and $1 \%$ level respectively.

\section{The Effects of Switching from the NYSE to Nasdaq}

The remainder of this paper focuses on the effects that are observed after the switch. Specifically, we examine changes in liquidity/trading costs as measured by quoted and relative bid ask spreads, changes in investor recognition/visibility as measured by the number and percentage of shares held by institutional investors and the number of analysts following the stock, and changes in profitability and valuation.

While our analysis is univariate, we control for significant confounding factors by utilizing a matchedfirm approach to examine changes in liquidity, changes in investor recognition, and changes in profitability and valuation. Our matched firms are found by identifying the NYSE firm in the same twodigit standard industry classification (SIC) code based on propensity score, which is the closest probability of being a Nasdaq firm based on our logistic regression in Table $4 .{ }^{19}$ For each variable of interest, we collect the raw value of the variable both before and after the switch to Nasdaq, and we calculate the change in the variable in question from the period prior to the switch to the period subsequent to the switch. We also conduct a difference-in-difference analysis and report the mean and median differences between our sample firms and their matched-peer control firms for the variable in question. 


\section{TABLE 6 \\ CHANGES IN SPREADS, VISIBILITY AND PROFITABILITY AROUND SWITCHES FROM THE NYSE TO NASDAQ}

In this table, we report quoted spreads and relative spreads averaged over 30 days before and 30 days after the switch, the number of institutional shareholders, percentage of shares held by institutions and number of analysts following, Fama and French (2000) profitability measure (calculated as earnings before interest and extraordinary items but after taxes divided by book assets), ROA, ROE and EPS growth, market-to-book ratio, debt issues normalized by assets and equity issues normalized by assets in the year prior to and following the switch. The first three columns report the mean and median values prior to the switch, subsequent to the switch and the change for our sample firms. The last three columns report the differences between our sample firms and their matched control firms.

\section{Panel A. Liquidity Measures}

\begin{tabular}{|l|c|c|c|}
\hline & \multicolumn{3}{|c|}{ Sample firms } \\
\hline Quoted spreads and relative spreads & Before Switch & After Switch & Change \\
\hline \multirow{2}{*}{ Quoted spread (\$1/10,000) } & 307.38 & 401.83 & $94.45^{* *}$ \\
& $(120.69)$ & $(157.14)$ & $(8.07)^{* * *}$ \\
\hline \multirow{2}{*}{ Relative spread (bsp) } & 26.67 & 35.43 & 8.76 \\
& $(9.93)$ & $(10.19)$ & $(0.41)$ \\
\hline & \multicolumn{3}{|c|}{ Difference between sample and control firms } \\
\hline Quoted spreads and relative spreads & Before Switch & After Switch & Change \\
\hline Quoted spread (\$1/10,000) & 132.46 & 271.52 & $139.06 * *$ \\
& $(0.00)$ & $(5.36)$ & $(21.69)^{* * *}$ \\
\hline Relative spread (bsp) & 18.17 & 30.68 & $12.51 *$ \\
& $(1.92)$ & $(2.16)$ & $(0.89)^{* *}$ \\
\hline
\end{tabular}

Panel B. Visibility Measures

\begin{tabular}{|l|c|c|c|}
\hline & \multicolumn{3}{|c|}{ Sample firms } \\
\hline \multicolumn{1}{|c|}{ Visibility } & 1 year before & 1 year after & Change \\
\hline \multirow{2}{*}{ Number of institutional investors } & $\begin{array}{c}251.40 \\
(257.63)\end{array}$ & $\begin{array}{c}283.55 \\
(266.38)\end{array}$ & $\begin{array}{c}32.15^{* * *} \\
(27.88)^{* * *}\end{array}$ \\
\hline $\begin{array}{l}\text { \% of shares held by institutional } \\
\text { investors }\end{array}$ & $\begin{array}{c}67.81 \\
(80.27)\end{array}$ & $\begin{array}{c}74.45 \\
(80.78)\end{array}$ & $\begin{array}{c}\mid c .64^{*} \\
(0.09)\end{array}$ \\
\hline Number of analysts following & 10.27 & 11.91 & $1.64^{* * *}$ \\
& $(9.50)$ & $(13.00)$ & $(1.50)^{* * *}$ \\
\hline \multirow{2}{*}{ Visibility } & Difference between sample and control firms \\
\hline \multirow{2}{*}{ Number of institutional investors } & 1 year before & $\mathbf{1}$ year after & Change \\
\hline \% of shares held by institutional & 57.91 & 73.83 & 15.92 \\
investors & $(5.75)$ & $(39.25)$ & $(14.25)$ \\
\hline \multirow{2}{*}{ Number of analysts following } & 7.03 & 8.96 & 1.93 \\
& $(2.19)$ & $(6.29)$ & $(0.50)$ \\
\hline
\end{tabular}


Panel C. Profitability Measures

\begin{tabular}{|c|c|c|c|}
\hline \multirow[b]{2}{*}{ Profitability } & \multicolumn{3}{|c|}{ Sample firms } \\
\hline & 1 year before & 1 year after & Change \\
\hline $\begin{array}{l}\text { Fama-French (2000) profitability } \\
\text { measure }\end{array}$ & $\begin{array}{c}0.0333 \\
(0.0408)\end{array}$ & $\begin{array}{c}0.0491 \\
(0.0617)\end{array}$ & $\begin{array}{c}0.0158 \\
(0.0062)\end{array}$ \\
\hline EPS growth & $\begin{array}{c}-0.3570 \\
(-0.2037)\end{array}$ & $\begin{array}{c}0.7569 \\
(0.0027)\end{array}$ & $\begin{array}{c}1.1138 \\
(0.1772)\end{array}$ \\
\hline ROA & $\begin{array}{c}0.0201 \\
(0.0344)\end{array}$ & $\begin{array}{c}0.0366 \\
(0.0528)\end{array}$ & $\begin{array}{c}0.0166 \\
(0.0051)\end{array}$ \\
\hline \multirow[t]{2}{*}{$\mathrm{ROE}$} & $\begin{array}{c}0.0522 \\
(0.1002)\end{array}$ & $\begin{array}{c}0.0686 \\
(0.0957)\end{array}$ & $\begin{array}{c}0.0164 \\
(0.0056)\end{array}$ \\
\hline & \multicolumn{3}{|c|}{ Difference between sample and control firms } \\
\hline Profitability & 1 year before & 1 year after & Change \\
\hline $\begin{array}{l}\text { Fama-French (2000) profitability } \\
\text { measure }\end{array}$ & $\begin{array}{c}-0.0416 \\
(-0.0377)\end{array}$ & $\begin{array}{c}0.0051 \\
(0.0071)\end{array}$ & $\begin{array}{c}0.0467 \\
(0.0402)\end{array}$ \\
\hline EPS growth & $\begin{array}{c}0.6338 \\
(0.2652)\end{array}$ & $\begin{array}{c}0.3260 \\
(0.0820)\end{array}$ & $\begin{array}{l}-0.3078 \\
(-0.1896)\end{array}$ \\
\hline ROA & $\begin{array}{c}-0.0536 \\
(-0.0355)\end{array}$ & $\begin{array}{c}0.0078 \\
(0.0049) \\
\end{array}$ & $\begin{array}{c}0.0614 \\
(-0.0369) \\
\end{array}$ \\
\hline $\mathrm{ROE}$ & $\begin{array}{l}-0.1345 \\
(-0.0565)\end{array}$ & $\begin{array}{c}0.0081 \\
(0.0199)\end{array}$ & $\begin{array}{c}0.1426 \\
(0.0363)\end{array}$ \\
\hline
\end{tabular}

Panel D. Valuation

\begin{tabular}{|c|c|c|c|}
\hline & \multicolumn{3}{|c|}{ Sample firms } \\
\hline Valuation & 1 year before & 1 year after & Change \\
\hline \multirow[t]{2}{*}{ Market/book } & $\begin{array}{c}1.4860 \\
(1.2893) \\
\end{array}$ & $\begin{array}{c}1.5819 \\
(1.3287) \\
\end{array}$ & $\begin{array}{c}0.0959 \\
(0.1029) \\
\end{array}$ \\
\hline & \multicolumn{3}{|c|}{ Difference between sample and control firms } \\
\hline Valuation & 1 year before & 1 year after & Change \\
\hline Market/book & $\begin{array}{c}-0.0173 \\
(-0.0499)\end{array}$ & $\begin{array}{c}0.0440 \\
(0.0386)\end{array}$ & $\begin{array}{l}-0.6130 \\
(-0.0134)\end{array}$ \\
\hline
\end{tabular}

Asterisk superscripts, ${ }^{*}, * *, * * *$, represent statistical significance at the $10 \%, 5 \%$ and $1 \%$ level respectively

Liquidity or Trading Costs

We first examine whether the move to Nasdaq is associated with a change in liquidity or trading costs, as measured by quoted spreads and relative spreads. In the logit regression of Table 3 , both the quoted and relative spreads come in positive and significant, which means that the higher the spreads, the more likely a company is on Nasdaq. Although this implies that Nasdaq companies tend to have higher spreads than NYSE companies, it does not necessarily imply that spreads will increase for firms switching to Nasdaq. So now we look at what happened to the spreads of the switching companies.

In Panel A of Table 6, we report the mean and median (in parentheses) quoted and relative spreads for each switching firm and its matched peer averaged over the 30 days prior to and after the switching day. ${ }^{20}$ We calculate the change in the mean and median quoted and relative spreads and report a test of 
differences between the changes observed for the exchange-switching firms versus their matched peers. We express the quoted spread in dollars per $\$ 10,000$, and the relative spread as a percentage of the midpoint. We test for differences in the mean by a parametric $t$-test and for the median with a Wilcoxon non-parametric test. Due to skewness, we will focus our conclusions on the median results. ${ }^{21}$

For the switching firms, the median spread increases from around $\$ 121$ to $\$ 157$, which is statistically significant. The relative spread also increases, but the difference is not statistically significant. The insignificance of the relative spreads may be due to the fact that 34 of 49 firms had higher prices 30 days after the switch. In comparison to the control groups, we also observe increases in the median absolute and relative spreads that are statistically significant. Thus, the evidence suggests that the spreads of switching firms increased both on an absolute and relative basis compared to their peer firms that remained on the NYSE. Hence, it does appear that switching to Nasdaq lowers liquidity and is a potentially expensive move for investors in terms of increasing trading costs. However, as suggested by Aggarwal and Angel (1998), firms may not actually care about spreads, which are largely just a cost to retail and primarily short-term traders.

\section{Visibility}

A second possible effect of moving from the NYSE to Nasdaq is that it improves investor recognition or visibility. We use three proxies for visibility: the number of institutional investors, the percentage of shares held by institutional investors, and the number of analysts following the stock, which were used earlier in the descriptive statistics and the logit analysis. ${ }^{22}$

The results of our analysis of changes in visibility are reported in Panel B of Table 6 . The switching firms experience a significant increase in the median number of institutional investors from a year prior to the switch to the year after the switch, a difference of about 32 institutional investors, but the change is insignificant compared to their matched peers (the difference-in-difference is not significant). The switching firm also gained a marginally statistically significant increase $(10 \%$ level $)$ in the percentage of shares held by institutional investors, but again the difference relative to the control sample is not significant. Finally, the switching firms gained a small but statistically significant increase in the number of analysts following them, but the difference relative to the control firms is also not significant. Thus, overall, the switch to Nasdaq resulted in no significant gains in visibility, which is proxied by analyst coverage, number of institutional investors and percentage of shares held by institutional investors, compared to those of the match firms that remain on the NYSE.

\section{Profitability, Valuation, and Credit Rating}

Our final hypothesized effect of switching from the NYSE to Nasdaq is performance. Do companies generate better performance after switching? It is inconceivable that moving from the NYSE to Nasdaq could improve corporate performance, but it is reasonable to believe that companies might switch in anticipation of worse performance. This opportunistic timing does not directly explain the motivation for a switch, but it could indicate that companies feel that if they are considering moving, they should do so when they look their best. We test for opportunistic behavior by examining changes in profitability using growth in EPS, ROA and ROE, as well as the Fama and French (2000) criterion of profitability calculated as earnings before interest and extraordinary items but after taxes divided by total book assets. We also examine changes in valuation, as measured by the market-to-book ratio, and though not reported in the tables changes in credit ratings. Our results are reported in Panels $\mathrm{C}$ and D of Table 6. Although profitability does appear to improve in the year following the switch to Nasdaq, we do not observe any statistically significant changes in profitability, nor is there a change in the difference between our sample firms' profitability and their matched control firms. Similarly, in Panel D, we see that the market value relative to book value increases after the switch, but the difference is not statistically significant for either the mean or median. The switch simply is not associated with improved or degraded shareholder value on a relative basis.

We also find no incidence of widespread credit rating downgrades. While not shown here, only two of the 49 firms experienced a credit downgrade during the year following the switch. By comparison, 
from 2001-2014, for all rated firms, 14.77\% experienced a credit downgrade within a year. Five of the 49 switching firms, about $10 \%$, had a credit upgrade, while $11.29 \%$ of all firms experienced a credit upgrade from 2001-2014. Thus, there appear to be no unusual patterns in credit ratings, and if anything, credit ratings improved.

Thus, there is no evidence to suggest that companies perform better or worse after the switch.

\section{Sample Robustness and Other Concerns}

Kedia and Panchapagesan (2011) find that Nasdaq firms often switch to the NYSE ahead of important events such as mergers. To eliminate the possibility that these switches may have been motivated by other reasons, such as the anticipation of important firm-specific events, we examine the sample for the presence of two of the most important firm-specific events: new security issues and merger and acquisition activity. We find that the sample firms had a slightly smaller amount of new debt issues relative to total assets and a larger amount of new equity issues relative to total assets than do the control firms, but neither difference is statistically significant.

With respect to merger and acquisition activity, we check the Mergent online database produced by FTSE Russell and find that almost half of the sample (25 of 49 firms, 51\%) had some M\&A activity in the 12 months following the announcement. Although this may seem like a larger percentage of the sample, we check Compustat for the percentage of NYSE firms in general that engage in M\&A activity in each year from $2000-2014$ and find that the average is $46.5 \%$ with a maximum of $49.8 \%$ and a minimum of $43.2 \%$. Thus, the M\&A activity of our sample firms is no greater or less than that of NYSE firms in general.

\section{CONCLUSIONS}

Our research updates the body of extant literature on the competition between the New York Stock Exchange and Nasdaq by examining the recent trend of firms moving from the NYSE to Nasdaq. We attempt to explain why these firms switched exchanges and the answer seems to be "why not." We find no measurable evidence that moving from the NYSE to Nasdaq is economically beneficial. It may even be somewhat costly. Bid-ask spreads increase, but the firms do not bear these costs directly and may even view higher spreads as beneficial by discouraging speculation.

We also find that the firms that move are characteristically far more like the NYSE firms they leave than the Nasdaq firms they join. We also dispel the myth of an industry clientele effect. For example, we show that Nasdaq is no more of a tech-firm exchange than is the NYSE, nor are there any clientele effects across other industries, though we do see that the leaders of the industries of the switching firms tend to be on Nasdaq. Finally, we show that there is not much of a market reaction to the announcement of the move.

If the exchanges have reached a stage in their evolution in which a move is a virtually immaterial event and seems to occur only for soft reasons, the stock exchange industry has reached the mature and competitive plateau in its industry life cycle.

\section{ENDNOTES}

1. The New York Stock Exchange was created in 1817. Nasdaq evolved out of the old over-the-counter market and was formally launched in 1971. At one time, the American Stock Exchange was normally mentioned alongside the NYSE and Nasdaq as a major U. S. stock market. In 2007 the NYSE purchased a European exchanged called Euronext and became known as NYSE Euronext. In 2008 NYSE Euronext purchased the American Stock Exchange, which it currently operates as NYSE MKT LLC. In late 2013, NYSE Euronext was sold to ICE, the Intercontinental Exchange located in Atlanta. In 2014 ICE spun off Euronext as an IPO. There are a handful of other U. S. exchanges but none with the size and economic power as the NYSE and Nasdaq.

2. Interestingly, Nasdaq has often been referred to as a market and not an exchange, but that allusion is primarily reflective of a view that an exchange is a specific type of market in which participants meet face- 
to-face and any other form of trading is an over-the-counter market and not an exchange. Clearly this view is antiquated.

3. It should be noted that the NYSE and Nasdaq compete not only for listings of traditional shares and volume but also for listings and volume of the rapidly expanding ETF market. A recent article in the Wall Street Journal (Loder 2016) suggests that the NYSE is losing ground in its electronic Arca Exchange to rivals like Nasdaq in ETF listings and trading volume.

4. This point seems to be the public perception and that of the press (Jain 2014) but may not reflect reality. For instance, many tech companies are listed on the NYSE and many smaller oil and gas firms are listed on the Nasdaq. We will examine whether this type of industry clientele effect exists later in this paper.

5. The Furst and Van Horne studies were done before Nasdaq existed, and as such, related to the OTC market that evolved into Nasdaq.

6. The NYSE initial and continuous listing requirements are discussed later, but it should be noted that after initial listing, an NYSE-listed company can shrink somewhat in terms of numbers of shareholders, market capitalization, and profitability and still remain listed.

7. The sharp rise from 1994 to 1998 could also be because firms were encouraged by investment banks to list on the NYSE to take advantage of the NYSE's lower trading costs and investors' ability to place limit orders on the NYSE.

8. See Atkins and Dyl (1997) who show that the Nasdaq dealer market nearly double counts the number of shares traded. As Aggarwal and Angel (1998) note, this overstatement of volume can be a reason why a firm might prefer to be listed on Nasdaq. As they note, it can also facilitate repurchases which in a given day are typically limited by Rule $10 \mathrm{~b}-18$ to $25 \%$ of average daily volume; however, we do not observe any significant change in repurchase activity in our sample firms subsequent to their move to Nasdaq. Anderson and Dyl (2005) demonstrate that rather than mitigate the problem by providing a more accurate count, electronic networks exacerbate the problem.

9. For example, Southwest Airlines' symbol, LUV, is a reference to its primary hub, Love Field in Dallas. Some other symbols of this type are Sealy (ZZ), National Beverage (FIZZ), Olympic Steel (ZEUS), Avis Budget (CAR), Franklin Resources (BEN), Harley Davidson (HOG), and Molson (TAP).

10. http://www.reuters.com/article/us-nasdaq-nyse-tickers-idUSTRE4A663020081107.

11. This figure is based on the 36 firms that switched after the highest tier was created. Prior to that time, six firms switched to Nasdaq's higher tier.

12. In other words, the requirements for the Nasdaq Global Market are the same as for the old Nasdaq National Market, and the requirements of the Nasdaq Capital Market are the same as the old Nasdaq SmallCap Market. Current listing requirements for each tier are in Appendix 1. It should also be noted that Aggarwal and Angel (1998) mention that the NYSE has been known to waive listing requirements. They check 59 firms that moved from Nasdaq to the NYSE in 1995 and found 10 that did not meet the NYSE requirements. Clearly, the NYSE can set and break its own rules.

13. Current listing fees for the NYSE and Nasdaq are in Appendix 2. We do not have information on whether these fees were different when companies switched.

14. "Price impact" measures the deviation of the transaction price from the unperturbed price that would prevail had the trade not occurred. Essentially the price impact plus commissions is lower for smaller firms on Nasdaq, while it is lower for larger firms on the NYSE.

15. Involuntary switches include the following types of listings. In 2004, Nasdaq initiated an effort to attract NYSE-listed companies by launching a program in which NYSE-listed companies can list their shares on Nasdaq while continuing to be listed on the NYSE. In addition, some companies are delisted from the NYSE and later apply for listing on Nasdaq. Also, some NYSE companies are merged with or acquired by a Nasdaq company and ultimately become Nasdaq-listed. Finally, a spin-off can also result in separately listed companies which can end up with a listing transfer from the NYSE to Nasdaq. All of these cases are excluded, as they are likely motivated by reasons other than a pure voluntary departure from the NYSE to Nasdaq.

16. It should be noted that seven of the 49 firms that moved from NYSE to Nasdaq were originally on Nasdaq, moved to NYSE, and the moved back to Nasdaq. These seven firms are identified in Panel B of the table. The remaining 42 firms originally listed on the NYSE.

17. As previously mentioned, summaries of listing requirements and fees for the NYSE and Nasdaq are provided in Appendices 1 and 2.

18. Year fixed effects are particularly important because most of the moves occurred after the financial crisis of 2008-2009. 
19. The matching firm is, therefore, a firm that is in the same industry at the same time of the switch with the closest probability being a Nasdaq firm to the switching firm but did not switch. Matching on the propensity score reduces endogeneity concerns as well as providing for the control of other effects.

20. For the tests on spreads, the sample firm with the lowest value for the change in quoted spread is removed because it is an extreme outlier with a value lower than the lower outer fence, which is the Quartile $1-$ $3 *$ interquartile range. Including this observation in the sample misleadingly resulted in a significant decrease in the mean change in quoted spread before and after the switch for both the sample itself and for the difference between sample firms and control firms.

21. The mean results have different significance levels, but the directions of the changes are the same as those of the median.

22. As with the bid-ask spread data, the sample firm with the lowest change in percentage of shares held by institutional investors is removed because it is a mild outlier with a value lower than the lower inner fence, which is Quartile $1-1.5 *$ interquartile range.

\section{REFERENCES}

Aggarwal, R., \& Angel J. J. (1998). Optimal listing policy: Why Microsoft and Intel do not list on the NYSDE. Working paper, Georgetown University.

Anderson, A., \& Dyl E. (2005). Market structure and trading volume. Journal of Financial Research, 28, $115-131$.

Atkins, A., \& Dyl E. (1997). Market structure and reported trading volume: Nasdaq versus the NYSE. Journal of Financial Research, 20, 291-304.

Baker, H., Powell, G., \& Weaver, D. (1999). Does NYSE listing affect firm visibility? Financial Management, 28, 46-54.

Barclay, M. J., Christie, W. G., Harris, J. H., Kandel, E., \& Schultz, P. (1999). Effects of market reform on the trading costs and depth of Nasdaq stocks. The Journal of Finance, 54, 1-34.

Bessembinder, H., \& Herbert K. (1997a). A comparison of trade execution costs for NYSE and Nasdaq listed stocks. Journal of Financial and Quantitative Analysis, 32, 287-310.

Bessembinder, H., \& Herbert K. (1997b). A cross-exchange comparison of execution costs and information flow for the NYSE-listed stocks. Journal of Financial Economics, 46, 293-319.

Bessembinder, H. (1999). Trade execution costs on Nasdaq and the NYSE: a post-reform comparison. Journal of Financial and Quantitative Analysis, 34, 387-407

Chan, L., \& Josef L. (1997). Institutional equity trading costs: NYSE versus Nasdaq. Journal of Finance, $52,713-735$.

Chemmanur, T. J., He, J., \& Fulghieri, P. (2008). Competition and Cooperation among Exchanges: Effects on Corporate Cross-Listing Decisions and Listing Standards. Journal of Applied Corporate Finance, 20, 76-90.

Chou, R. (2005). The Impact of Limit Order Handling on the NYSE and Nasdaq Transaction Costs. Quarterly Journal of Business and Economics, 44, 67-88.

Christie, W. G., \& Huang, R. D. (1994). Market structures and liquidity: A transactions data study of exchange listings. Journal of Financial Intermediation, 3, 300-326.

Christie, W. G., \& Schultz P. H. (1994). Why do Nasdaq market-makers avoid odd eighth quotes? Journal of Finance, 49, 1813-1840.

Chung, K. H., Van Ness, B., \& Van Ness, R. (1999). Limit orders and the bid-ask spread. Journal of Financial Economics, 53, 255-287.

Chung, K. H., Van Ness, B., \& Van Ness, R. (2001). Can the treatment of limit orders reconcile the differences in trading costs between NYSE and NASDAQ issues? Journal of Financial and Quantitative Analysis, 36, 267-286.

Chung, K. H., Van Ness, B., \& Van Ness, R. (2004). Trading Costs and Quote Clustering on the NYSE and NASDAQ after Decimalization. Journal of Financial Research, 27, 309-328.

Clyde, P., Schultz P., \& Zaman M. (1997). Trading costs and exchange delisting: The case of firms that voluntarily move from the American Stock Exchange to the Nasdaq. The Journal of Finance, 52, 2103-2112. 
Cowan, A. R., Carter, R. B., Dark, F. H., \& Singh, A. K. (1992). Explaining the NYSE listing choices of Nasdaq firms. Financial Management, 21, 73-86.

Dang, A. D., Michayluk D., \& Pham T. P. (2018). The curious case of changes in trading dynamics when firms switch from NYSE to Nasdaq. Journal of Financial Markets, 41, 17-35.

Dharan, B. G., \& Ikenberry D. L. (1995). The Long-Run Negative Drift of Post-Listing Stock Returns. Journal of Finance, 50, 1547-1574.

Fama, E., \& French K. (2000). Forecasting profitability and earnings. The Journal of Business, 73, 161175.

Furst, R. W. (1970). Does listing increase the market price of common stock? The Journal of Business, $43,174-180$.

He, Y., \& Wu C. (2003). The post-reform bid-ask spread disparity between Nasdaq and the NYSE. Journal of Financial Research, 26, 207-24.

Huang, R. D., \& Hans R. S. (1996). Dealer versus auction markets: A paired comparison of execution costs on NASDAQ and NYSE. Journal of Financial Economics, 41, 313-358.

Hiltzik, M. (2014, October). End of an era: The NYSE floor isn't even good for PR photos anymore. Los Angeles Times. Retrieved from http://beta.latimes.com/business/hiltzik/la-fi-mh-the-nyse-floor20141007-column.html

Jain, S. (2014, September). Why is the NASDAQ heavily weighted towards technology stocks? Market Realist. Retrieved from http://marketrealist.com/2014/09/nasdaq-heavily-weighted-towardstechnology-stocks/

Kadlec, G., \& McConnell, J. (1994). The effect of market segmentation and illiquidity on asset prices: Evidence from exchange listings. Journal of Finance, 49, 611-636.

Kalay, A., \& Portniaguina E. (2001). Swimming against the tides: The case of Aeroflex move from NYSE to Nasdaq. Journal of Financial Markets, 4, 261-267.

Kedia, S., \& Panchapagesan, V. (2011). Why do only some Nasdaq firms switch to the NYSE? Evidence from corporate transactions. Journal of Financial Markets, 14, 109-126.

Keim, D. B., \& Madhavan A. (1997). Transactions costs and investment style: An inter-exchange analysis of institutional equity trades. Journal of Financial Economics, 46, 265-292.

LaPlante, M., \& Chris J. M. (1997). Do institutions receive comparable execution in the NYSE and Nasdaq markets? A transaction study of block trades. Journal of Financial Economics, 45, 97 134.

Lin, W. C., \& Liao, T. L. (2015). Exchange listing type and firm financial reporting behavior. International Review of Economics and Finance, 38, 234-249.

Loder, A. (2016, December). NYSE Arca losing ETFs to rivals. The Wall Street Journal. Retrieved from https://www.wsj.com/articles/nyse-arca-losing-etfs-to-rivals-1482882194.

Merton, R. C. (1987). Presidential address: A simple model of capital market equilibrium with incomplete information. Journal of Finance, 42, 483-510.

Pruitt, S.W., Van Ness, B., \& Van Ness, R. (2002). The first of many? The microstructure effects of Aeroflex corporation's jump from NYSE to the Nasdaq. Journal of Applied Finance, 12, 46-54.

Reinganum, M. R. (1990). Market microstructure and asset pricing: An empirical investigation of NYSE and Nasdaq Securities. Journal of Financial Economics, 28, 127-148.

Sanger, G. C., \& McConnell J. J. (1986). Stock exchange listing, firm value and security market efficiency: The impact of the Nasdaq. Journal of Financial and Quantitative Analysis, 21, 1-25.

Sanger, G. C., \& McConnell J. J. (1987). The Puzzle in Post-Listing Common Stock Returns. Journal of Finance, 119-140.

Schultz P. (2000). Regulatory and Legal Pressures and the Costs of Nasdaq Trading. Review of Financial Studies, 13, 917-957.

Van Horne, J. C. (1970). New listings and their price behavior. The Journal of Finance, 25, 783-794.

Weston, J. P. (2000). Competition on the NASDAQ and the impact of recent market reforms. Journal of Finance, 55, 2565-2598. 


\section{APPENDIX 1 \\ NASDAQ AND NYSE CURRENT LISTING REQUIREMENTS}

This table is a summary of the most pertinent initial and continued listing requirements for the NYSE and Nasdaq. It is not an exhaustive list of the requirements. The full initial and continuing listing requirements for the NYSE and Nasdaq can be found on their respective websites.

\begin{tabular}{|c|c|c|}
\hline & \multicolumn{2}{|c|}{ NYSE } \\
\hline Requirement & Initial & Continuing \\
\hline Pre-tax income & $\begin{array}{l}\text { Aggregate pre-tax income for } \\
\text { last } 3 \text { years }>\$ 10 \mathrm{~mm}\end{array}$ & \\
\hline Global market capitalization & $>\$ 200 \mathrm{~mm}$ & \\
\hline Shareholders & $>400$ round lot shareholders & $>300$ round lot shareholders \\
\hline Publicly held shares & $>1.1 \mathrm{~mm}$ & $>200,000$ \\
\hline Market value of public shares & $>\$ 40 \mathrm{~mm}$ & $>\$ 1 \mathrm{~mm}$ \\
\hline Minimum share price & $>=\$ 4.00$ & $\begin{array}{l}\text { Common stock sells for a low } \\
\text { price for a substantial time. }\end{array}$ \\
\hline \multirow[t]{2}{*}{ Average monthly trading volume } & & $>100,000$ shares \\
\hline & \multicolumn{2}{|c|}{ Nasdaq } \\
\hline Requirement & Initial & Continuing \\
\hline Pre-tax income & $\begin{array}{l}\text { Nasdaq Global select: } \\
\text { 3-year aggregate pre-tax income } \\
\text { > } \$ 11 \mathrm{~mm} \\
\text { Nasdaq Global market: } \\
>\$ 1 \mathrm{~mm}\end{array}$ & \\
\hline \multicolumn{3}{|l|}{ Global market capitalization } \\
\hline Shareholders & $\begin{array}{l}\text { Nasdaq Global select: } \\
>450 \text { round lot } \\
\text { Nasdaq Global market: } \\
>400 \text { round lot } \\
\text { Nasdaq Capital market: } \\
>300\end{array}$ & $\begin{array}{l}\text { Nasdaq Global select: } \\
>400 \\
\text { Nasdaq Global market: } \\
>400 \\
\text { Nasdaq Capital market: } \\
>300\end{array}$ \\
\hline Publicly held shares & $\begin{array}{l}\text { Nasdaq Global select: } \\
>1.25 \mathrm{~mm} \\
\text { Nasdaq Global market: } \\
>1.1 \mathrm{~mm} \\
\text { Nasdaq Capital market: } \\
>750,000\end{array}$ & $\begin{array}{l}\text { Nasdaq Global select: } \\
>750,000 \\
\text { Nasdaq Global market: } \\
>750,000 \\
\text { Nasdaq Capital market: } \\
>500,000\end{array}$ \\
\hline Market value of public shares & $\begin{array}{l}\text { Nasdaq Global select: } \\
\text { > \$110mm } \\
\text { Nasdaq Global market: } \\
>\text { > } 20 \mathrm{~mm} \\
\text { Nasdaq Capital market: } \\
>\$ 15 \mathrm{~mm}\end{array}$ & $\begin{array}{l}\text { Nasdaq Global select: } \\
>\$ 5 \mathrm{~mm} \\
\text { Nasdaq Global market: } \\
>\$ 5 \mathrm{~mm} \\
\text { Nasdaq Capital market: } \\
>\$ 1 \mathrm{~mm}\end{array}$ \\
\hline Minimum share price & $\begin{array}{l}\text { Nasdaq Global select: } \\
>=\$ 4.00 \\
\text { Nasdaq Global market: } \\
>=\$ 4.00 \\
\text { Nasdaq Capital market: } \\
>=\$ 3.00\end{array}$ & $\begin{array}{l}\text { Nasdaq Global select: } \\
>=\$ 1.00 \\
\text { Nasdaq Global market: } \\
>=\$ 1.00\end{array}$ \\
\hline
\end{tabular}




\section{APPENDIX 2 \\ NASDAQ AND NYSE CURRENT LISTING FEES}

\begin{tabular}{|c|c|c|c|}
\hline \multicolumn{4}{|c|}{ Nasdaq } \\
\hline \multicolumn{2}{|c|}{$\begin{array}{l}\text { Nasdaq Global Select Market } \\
\text { and Nasdaq Global Market }\end{array}$} & \multicolumn{2}{|c|}{ Nasdaq Capital Market } \\
\hline Entry Fees & Annual Listing Fees & Entry Fees & $\begin{array}{l}\text { Annual Listing } \\
\text { Fees }\end{array}$ \\
\hline $\begin{array}{l}\text { Up to } 30 \text { million: } \\
\$ 125,000 \text {, including } \\
\$ 25,000 \text { application fee } \\
30+\text { to } 50 \text { million: } \\
\$ 150,000 \text {, including } \\
\$ 25,000 \text { application fee } \\
50+\text { to } 100 \text { million: } \\
\$ 200,000 \text {, including } \\
\$ 25,000 \text { application fee } \\
\text { Over } 100 \text { million: } \\
\$ 225,000 \text {, including } \\
\$ 25,000 \text { application fee }\end{array}$ & $\begin{array}{l}\text { Up to } 50 \text { million } \\
\text { shares: } \$ 40,000 \\
\text { 50+ to } 75 \text { million } \\
\text { shares: } \$ 46,500 \\
75+\text { to } 100 \text { million } \\
\text { shares: } \$ 69,000 \\
\text { 100+ to } 125 \text { million } \\
\text { shares: } \$ 93,000 \\
\text { Over } 125 \text { million } \\
\text { shares: } \$ 125,000\end{array}$ & $\begin{array}{l}\text { Up to } 15 \text { million: } \$ 50,000 \text {, } \\
\text { including } \$ 5,000 \\
\text { application fee } \\
\text { Over } 15 \text { million: } \\
\$ 75,000 \text {, including } \\
\$ 5,000 \text { application fee }\end{array}$ & $\begin{array}{l}\text { Up to } 10 \text { million } \\
\text { shares: } \$ 32,000 \\
\text { 10+ to } 50 \text { million } \\
\text { shares: } \$ 40,000 \\
\text { Over } 50 \text { million } \\
\text { shares: } \$ 45,000\end{array}$ \\
\hline \multicolumn{4}{|c|}{ NYSE } \\
\hline \multicolumn{2}{|c|}{ Entry Fees } & \multicolumn{2}{|c|}{ Annual Listing Fees } \\
\hline \multicolumn{2}{|c|}{$\begin{array}{l}\text { Initial Application fee of } \$ 25,000 \\
\$ 0.0032 \text { per share and a special one-time charge of } \\
\$ 50,000 \text {. }\end{array}$} & \multicolumn{2}{|c|}{ 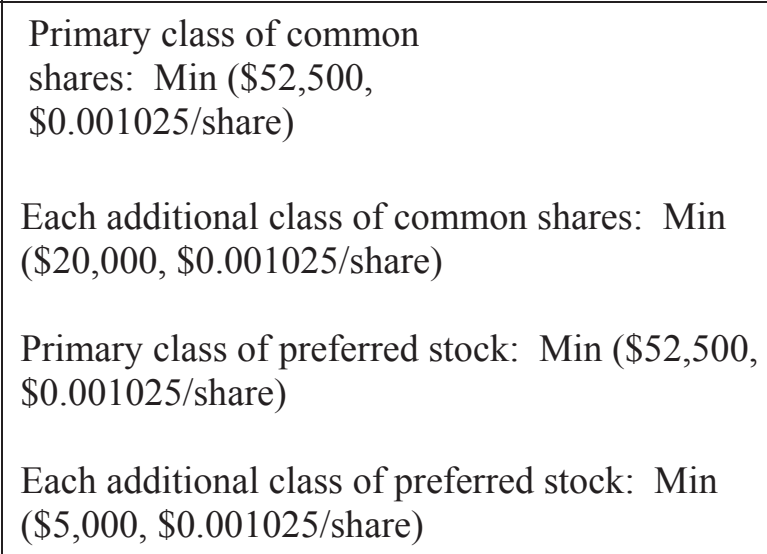 } \\
\hline
\end{tabular}

Note: For Nasdaq, annual fees are based on the company's total shares outstanding as of December 31 of the prior year for all classes of equity. For NYSE, the annual fee for each class of equity security listed is different and is equal to the greater of the minimum fee or the fee calculated on a per share basis. The first time that an issuer lists a class of common shares, it is also subject to a one-time special charge of $\$ 50,000$, in addition to fees calculated according to the above schedule. 


\section{APPENDIX 3 \\ FIRMS VOLUNTARILY MOVING FROM THE NYSE TO NASDAQ}

Panel A. All Companies

\begin{tabular}{|c|c|c|}
\hline Company Name & Announcement Date & Switch Date \\
\hline Aeroflex Inc. & $2 / 17 / 2000$ & $3 / 21 / 2000$ \\
\hline Industrial Distribution Group Inc. & $5 / 26 / 2004$ & $6 / 2 / 2004$ \\
\hline Nashua Corp. & $9 / 7 / 2005$ & $9 / 13 / 2005$ \\
\hline Tasty Baking Company & $10 / 18 / 2005$ & $10 / 21 / 2005$ \\
\hline Innospec Inc. & $3 / 15 / 2006$ & $3 / 22 / 2006$ \\
\hline Liberty Media Corporation & $5 / 3 / 2006$ & $5 / 10 / 2006$ \\
\hline Computer Task Group Inc. & $5 / 26 / 2006$ & $6 / 5 / 2006$ \\
\hline E*TRADE Financial Corporation & $12 / 14 / 2006$ & $12 / 27 / 2006$ \\
\hline The DIRECTV Group & $11 / 15 / 2007$ & $12 / 3 / 2007$ \\
\hline C A Inc. & $4 / 16 / 2008$ & $4 / 28 / 2008$ \\
\hline Seagate Technology & $8 / 27 / 2008$ & $9 / 16 / 2008$ \\
\hline Automatic Data Processing, Inc. & $9 / 26 / 2008$ & $10 / 21 / 2008$ \\
\hline Jack In The Box & $12 / 1 / 2008$ & $12 / 15 / 2008$ \\
\hline Mylan Laboratories & $12 / 12 / 2008$ & $12 / 29 / 2008$ \\
\hline News Corporation & $12 / 16 / 2008$ & $12 / 29 / 2008$ \\
\hline DreamWorks Animation & $2 / 13 / 2009$ & $2 / 26 / 2009$ \\
\hline Network Equipment Technologies & $4 / 13 / 2009$ & $4 / 24 / 2009$ \\
\hline Donnelley R \& Sons Co. & $7 / 23 / 2009$ & $8 / 5 / 2009$ \\
\hline TriMas Corporation & $8 / 12 / 2009$ & $8 / 24 / 2009$ \\
\hline Mattel Inc. & $9 / 14 / 2009$ & $9 / 28 / 2009$ \\
\hline Vodafone Group Plc & $10 / 12 / 2009$ & $10 / 29 / 2009$ \\
\hline B M C Software Inc. & $10 / 13 / 2009$ & $10 / 26 / 2009$ \\
\hline Cypress Semiconductor Corp. & $10 / 30 / 2009$ & $11 / 12 / 2009$ \\
\hline Windstream Corp. & $11 / 25 / 2009$ & $12 / 10 / 2009$ \\
\hline Micron Technology Inc. & $12 / 18 / 2009$ & $12 / 30 / 2009$ \\
\hline Winner Medical & $3 / 19 / 2010$ & $4 / 6 / 2010$ \\
\hline Potlatch & $12 / 6 / 2010$ & $12 / 17 / 2010$ \\
\hline Hasbro & $12 / 9 / 2010$ & $12 / 21 / 2010$ \\
\hline Avis Budget Group Inc. & $12 / 20 / 2010$ & $12 / 31 / 2010$ \\
\hline Viacom & $11 / 11 / 2011$ & $12 / 1 / 2011$ \\
\hline Fifth Street Financial & $11 / 16 / 2011$ & $11 / 28 / 2011$ \\
\hline SLM CORP & $11 / 21 / 2011$ & $12 / 12 / 2011$ \\
\hline Icahn enterprises & $11 / 28 / 2011$ & $12 / 12 / 2011$ \\
\hline Frontier Communications Corp. & $12 / 2 / 2011$ & $12 / 16 / 2011$ \\
\hline Magnetek Inc. & $12 / 9 / 2011$ & $12 / 20 / 2011$ \\
\hline Wendys Co. & $12 / 13 / 2011$ & $12 / 27 / 2011$ \\
\hline Texas Instruments Inc. & $12 / 15 / 2011$ & $1 / 3 / 2012$ \\
\hline
\end{tabular}


Analog Devices Inc.

$3 / 13 / 2012$
$4 / 2 / 2012$

Western Digital Corp.

$5 / 21 / 2012$

$6 / 1 / 2012$

Kraft Foods Group Inc.

$6 / 8 / 2012$

$6 / 26 / 2012$

Goodyear Tire \& Rubber Co.

$12 / 7 / 2012$

$12 / 18 / 2012$

LSI Corporation

$12 / 7 / 2012$

$12 / 19 / 2012$

Alliance HealthCare Services Inc.

$1 / 31 / 2013$

$2 / 11 / 2013$

Community Bankers Trust Corp.

$2 / 28 / 2013 \quad 3 / 14 / 2013$

Vanguard Natural Resources, LLC.

$4 / 11 / 2013$

$4 / 23 / 2013$

MoneyGram International Inc.

$4 / 23 / 2013$

$5 / 13 / 2013$

Old National Bancorp

$7 / 25 / 2013$

$8 / 14 / 2013$

VimpelCom Ltd.

$8 / 7 / 2013$

$9 / 10 / 2013$

Marriott International Inc.

$10 / 7 / 2013$

$10 / 21 / 2013$

Panel B. Companies that were on Nasdaq, switched to the NYSE, and then switched back to Nasdaq Company Name Nasdaq to NYSE switch year NYSE to Nasdaq switch year Cypress Semiconductor Corp 1988 Network Equipment 1989 2009

Technologies

B M C Software Inc

Old National Bancorp

Frontier Communications Corp

1992

2013

C A Inc

1986

2011

Computer Task Group Inc

1987

2008

2006 